\title{
Distances and Small Business Credit Constraints: The French case
}

\author{
Salima Djedidi Kooli
}

\begin{abstract}
Deregulation and progress in information and communication technologies have increased the geographical expansion of banking structures and instruments. This makes banks operationally close to the borrowers. At the same time, banking industry consolidation have induced a geographical concentration of banking decision centers and strategic functions, leading to an increase of the functional distance that separates the decision center of a bank from its operational branches. The aim of this paper is to evaluate the impact of these two trends on small and medium-sized enterprise (SME) lending. Our findings on French data suggest that (i) increased functional distance induces an increase of the investment cash flow sensitivity considered as a measure of financing constraints and that (ii) the relationship between operational proximity and financing constraints is non linear with an investment-cash flow relationship supposed to be increasing for low levels of operational proximity below a certain threshold and decreasing for high levels of it. The adverse effect of functional distance on financing constraints is particularly acute for small firms.
\end{abstract}

Keywords: SME lending, functional distance, operational proximity, financing constraints, investment-cash flow sensitivity

JEL Classification: G21, G34, R51

\section{Introduction}

Over the last two decades in France, all credit institutions categories have known a substantial decrease of their establishments' number (see Appendix A, Figure A.1.). This decrease was about $22 \%$ for commercial banks over the period 1997 to 2008. It was about $36 \%$ for mutual and cooperative banks over the same period (see Appendix A, Figure A.2.).

This fall of the bank's number have been following a longstanding trend. Thus, since the law bank of January 24, 1984, the French banking sector have been engaged in an intense movement of restructuring, which resulted in a steady decrease of the number of credit institutions. This decline was about $64 \%$ for credit institutions established in France (excluding Monaco) during the period 1984 to 2008.

${ }^{1}$ LEDA - SDFi, Université Paris-Dauphine, Place du Maréchal de Lattre de Tassigny, 75775 Paris CEDEX 16, France, e-mail: salima.djedidi@dauphine.fr; djedidi.salima@voila.fr 
The dynamic movement of reorganization and renovation of banking structures has been accompanied by a strengthening, since the early 2000s, of the banking system's supply (see Appendix A, Figure A.3.). In fact, the number of branches, which was maintained during fifteen years in a range of 25500 to 26000 , is in progress since 2000 (27893 at the end of 2008 excluding branches of the postal bank). Also, the number of Automated Teller Machines (ATMs), which exceeds that of branches since 1997, almost doubled over the last ten years. Finally, the information and communication technology progress favored the expansion of impersonal methods to conduct businesses, such as Internet-banking, home-banking, or phone-banking. These changes reflect a research of productivity gains among French credit institutions, a strong dynamism and also a deep technological change in distribution channels.

Both of these phenomena have a spatial dimension. The geographical diffusion of banking structures and instruments contributed to the ease of access to banking services by savers and borrowers established locally. It refers to the so called 'operational distance' considered in the banking literature. It largely depends on the physical distance that separates banks from their clientele. With respect to organizational structure, the wave of mergers and acquisitions that have reduced the number of banks and have created large national and multinational bank holding companies, have induced a geographical concentration of banking decision centers and strategic functions, leading to an increase in the 'functional distance ${ }^{1}$ that separates the decision center of a bank from its operational branches.

In this paper, we focus on the French banking industry in order to assess the effects of these contrasting trends of spatial diffusion-concentration on financing constraints for local SMEs.

A large literature is devoted to assessing the impact of banking consolidation on local development. The vast majority of these studies follow a bank-based approach where they compare the lending behavior of small banks, theoretically considered as best suited to deliver relationship lending and therefore considered 'close' to the need of local small and medium-sized enterprises (SMEs), with the lending behavior of large banks, considered as more 'distant'. They find differences in relationship lending with larger institutions tending to lend to older and larger SMEs with stronger financial statements (Haynes and Berney, 1999; Cole et al., 2004; Scott, 2004; Berger et al., 2005). There is also evidence that as lending decisions are taken at higher layers of the organizational structure, there is less emphasis on soft information penalizing small opaque firms (Liberti and Mian, 2009).

A few other studies follow a market based approach, where the analysis is carried out at the local market level (Avery and Samolyk, 2000; Berger et al., 2007; Bonaccorsi di Patti and Gobbi, 2001; Collender and Shaffer, 2003). This approach has the advantage of directly assessing the net impact of banking industry structure on local borrowers.

In this paper, we follow the same market-based approach adopted by Alessandrini et al. (2009) and try to evaluate the impact of the two trends of diffusion-concentration of the banking system on SME financing. Following Alessandrini et al. (2009), we have

\footnotetext{
${ }^{1}$ This terminology was introduced by Alessandrini, Croci and Zazzaro (2005) and subsequently used in several studies.
} 
tried to overcome the oversimplification of the morphological structure's measure of the local banking industry provided in the literature by introducing a more accurate measure of the functional distance of local banking systems from local economies. Using a pooled sample of 2174 French SMEs, we find that both operational and functional distances play a significant role in explaining financing constraints of local firms.

The remainder of the paper is organized as follows. The next section presents the main theoretical and empirical works related to our subject. Section 3 describes the data and the distance variables. Section 4 displays the dynamic investment econometric model performed and the different results obtained. The last section concludes.

\section{Related Literature}

\subsection{Distance and lending decisions: theory and evidence}

Economic theory recognize physical distance as causing potentially relevant economic costs for both the bank granting a credit and the firm seeking financing. These costs are not only pecuniary such as transportation costs, but also may be informational costs induced by the extra efforts required from the bank to access the creditworthiness of potential borrowers or to monitor firm's investments.

In theoretical models founded on information asymmetries, credit rationing may be the bank's optimal response to the deterioration of the quality of information on distantly located firms. Petersen and Rajan (2002) argue that as the severity of the asymmetric information problem intensifies with distance, local lenders can collect soft information on small firms over time and can strategically use their informational advantage to create a threat of adverse selection for more remote competitors who might not enjoy the same degree of access to local information. Hauswald and Marquez (2006) make this notion more precise by developing a model where the quality of a bank's proprietary information is negatively related to the physical distance between bank and borrower to capture the varying degrees of informational expertise present in modern banking. Because banks receive more precise signals about close borrowers, competing banks face increasing adverse selection problems when approaching these locally captured firms. As the distance between the borrower and the informed bank ${ }^{2}$ increases, this bank's information advantage decreases, and the uninformed bank ${ }^{3}$ is able to bid more frequently so that, in equilibrium, the likelihood of a competing loan offer increases in bank-borrower distance. Hence, the spatial pricing model based on informational asymmetries developed by Hauswald and Marquez (2006) show that geographical credit rationing by banks can occur in equilibrium, where the underlying rationale is an adverse selection mechanism à la Stiglitz and Weiss (1981). Type II errors in credit offers always increase on the bank borrower distance but the effect on type I errors is ambiguous and depends on the quality of information.

\footnotetext{
2 The closest bank from the borrower.

${ }^{3}$ The closest competitor from the informed bank.
} 
A simple theoretical model to rationalize the existence of geographical credit rationing developed by Carling and Lundberg (2005) leads to a similar prediction than in Hauswald and Marquez (2006). They also suggest that the creditworthiness signal's quality is decreasing in the borrower's distance to the bank and demonstrate that the bank's optimal strategy is to turn down credit applicants from some distantly located firms.

To summarize, we could suppose that the relationship between the distance and credit rationing is non linear. In fact, when the distance is low (the quality of the signal is high), the probability that the informed bank correctly identifies the borrower increases toward one, then the likelihood of doing type I and II errors is low as well as the probability of credit rationing equilibrium. As long as the distance increases but remains at a level that is below a certain threshold, the likelihood of doing type I and II errors increases as well as the probability of credit rationing equilibrium. For values of distance that are above this threshold, the quality of the signal is very bad for informed banks and the uninformed lender faces a less severe adverse selection threat and is therefore more likely to extend a loan offer.

Empirical findings on the effects of physical proximity of banks to borrowers are mixed. At the bank level, Petersen and Rajan (2002) find that remote applicants are more likely to be declined credits in the U.S. but this effect is strongly decreasing over time. In contrast, Agarwal and Hauswald (2010) find that credit availability decrease with the bank-borrower distance and increase with the borrower-competitor distance. However, the statistical significance of these relations disappears when they control for the bank's proprietary information (the bank's internal credit score) concluding that the geographical distance is a simple proxy for lender's informational advantage. However, Carling and Lundberg (2005), using data on corporate loans granted between 1994 and 2000 by a leading Swedish bank, find no evidence of geographical credit rationing. Uchida et al. (2008), using a unique Japanese data set and the same methodology as Berger et al. (2005) obtained no evidence of geographical credit rationing in Japan.

At the market level, Avery and Samolyk (2000), using U.S. data, find that the number of banks operating in a Metropolitan Statistical Area is positively but weakly related to the growth rate of SME's loans in the local market, whereas the number of offices has no impact at all on this growth rate. Using Italian data, Bonaccorsi di Patti and Gobbi (2001) find that the branch density (the ratio of branches to population) in a province is positively related to the volume of credit for small borrowers but it is negatively associated with the volume of bad loans. Benfratello et al. (2008), using a rich data set on innovation at the firm level for a large number of Italian firms over the 90's, find that the banking development (computed as the number of branches divided by population) affects positively the probability of process innovation, particularly for small firms and for firms in high(er) tech sectors and in sectors more dependent upon external finance. There is also some evidence that banking development reduces the cash flow sensitivity of fixed investment spending, particularly for small firms. 


\subsection{Why the geographical distribution of banks' decisional centers should affects small business lending? theory and evidence}

The process of financial integration in the European and U.S. banking industry in the 1990s was accompanied by the debate about the benefits of strengthened competition in credit markets, greater efficiency and the geographical reach of banking groups through affiliated banks and branches. This would have assured an adequate response to the need of local economies. However, the growing body of research examining the effects of bank consolidation and organizational structure on lending policies raises the question, for a long time neglected, of the cost of the predictable geographical concentration of decisional centres and the increasing size and complexity of bank organisation induced by the spectacular wave of bank mergers and acquisitions. Put differently, this body of research highlights the fact that the organizational complexity of the institutions to which the loan office belongs is as much important as the operational proximity in the process of credit allocation to small businesses.

Academics assess the potential implications of induced changes in the banks organizational structure on small business lending by analyzing organizational theories. The general outcome of these theories is that small banks should be more inclined than large and complex banks to extend credits to small and opaque firms. The main argument supporting this claim is the existence of organizational diseconomies that limit the scope of large banks in their lending activities. The motivation of such organizational diseconomies has been widely debated by academics using several theories but it seems that they come from a common origin - the inherent difference between small business lending and transactions-based lending.

In small business lending, the bank bases its credit decisions largely on private or soft information about the firm and its owner that is collected through multiple interactions over time and across products (Boot, 2000; Berger and Udell, 2002). Soft information may confer the bank with a competitive informational advantage over banks that base their decision on public information and thus obtain a more precise signal of the creditworthiness of the firm. However, the collection method of this information needs to be personal, making soft information hardly verifiable and thus difficult to transmit to upper echelons of banking organization and to store (Stein, 2002). Therefore, the lack of adequate soft information transmission channels within a bank requires organizational adjustments, which is costly (Crémer et al., 2007).

The idea that a centralized bank (e.g. a large bank holding company) is less competent in relationship lending than a decentralized bank (e.g. a small community bank) has been theoretically demonstrated by Stein (2002) that shows that in hierarchically complex organizations, loan officers have less incentive to collect soft information since they are excluded from the decision making but have to report that information to their superiors. However, information research efforts by loan officers are well recognized by a decentralized organization that ensure to them access to funds necessary to capitalize on that expertise. 
Berger and Udell (2002) suggest a different mechanism to motivate the existence of organizational diseconomies in large banks. It consists on internal agency problems between the loan officer - considered as a receptacle of soft information-and his superior and stem from the intangible nature of soft information and, in particular, from the difficulty in diffusing this information within a large and complex organisation. The necessary tradeoff between delegation and control have been analyzed in the principal-agent theory In fact, Udell (1989) and Berger and Udell (2002) show that the specialization in relationship lending (e.g. small business lending) should go hand in hand with more investment in loan officers control. This endows small decentralized banks with another source of comparative advantage in small business lending.

A considerable research effort has been devoted to empirically test the relation between bank's organizational structure and credit availability to small firms. First, numerous studies show that bank organizational complexity implies a reduction in the availability of credit to small businesses (Berger et al., 1999). Small firms are, in fact, highly dependent on bank financing (Berger and Udell, 1998; Cole et al., 1996) and this is aggravated by the evidence that large banks allocate fewer resources to small business lending than do small banks because they have a real competitive disadvantage in evaluating their creditworthiness (Berger and Udell, 1996; Keeton, 1995; Peek and Rosengren, 1996; De Young et al., 1999; Alessandrini et al., 2008; Sapienza, 2002). Contradictory evidence are provided by Jayaratne and Wolken (1999) that find that the SME rationing probability is not significantly related to the presence of small banks in the market, suggesting the absence of a cost advantage of small banks in originating credit to small borrowers.

When focusing on the empirical literature analysing the impact of mergers and acquisitions (M\&As) on credit supply to small firms, we notice the lack of consensus on this issue. On the one hand, Strahan and Weston $(1996 ; 1998)$ show that small bank M\&As have a positive effect on small business lending, however Berger et al. (1998) and Peek and Rosengren (1998) find that large bank M\&As have the opposite effect.

At the market level, Bonaccorsi di Patti and Dell'Ariccia (2004) find that the creation of industrial firms in a giving province in Italy is positively associated with the share of deposits held by banks headquartered in the same province (one measure of functional distance). Collender and Shaffer (2003), studying the impact of functional distance on local economic growth, find that the impact of the number of bank offices operating locally on local economic growth differs significantly with the locus of their ownership.

\subsection{Why SMEs may be financially constrained?}

The availability of external finance for SMEs is a topic of significant research interest to academics and an issue of great importance to policy makers around the globe. Bank credit still remains the major source of external financing for SMEs. In fact, a conventional wisdom in the contemporary corporate finance literature argues that problems of information asymmetry, described by Jensen and Meckling (1976), Myers and Majluf (1984) and Stiglitz and Weiss (1981), are particularly acute for SMEs (Ang, 1991; Carpenter 
and Petersen, 2002), since beyond the shareholders' motivation of avoiding the dilution of ownership and their desire to keep control of the business, the prosperity of SMEs is affected by hidden information, the lack or low level of collateral and the lack of any history or reliable financial information and audited accounting records (Holmes and Kent, 1991; Ang, 1991; Chittenden et al., 1996; Berger and Udell, 1998). The lack of sufficient information to determine the quality of different investment projects in the SME as well as the quality of management for making investment decisions determines the level of risk that external creditor face. A high level of risk (a high level of opacity) is then reflected through the credit denial decision. It is important to note that the implication of asymmetric information is not that lending to SMEs is necessarily a risky job but that the assessment of this risk is challenging.

In this paper, we aim to evaluate the impact of the changing structure of the French banking system in terms of higher diffusion-concentration on local firms financing constraints. We particularly address the issues of endogeneity of functional distance and operational proximity, used as measures of this diffusion-concentration, as well as omitted variables by using system GMM estimations. Also, we take the same new measure of local banking structure adopted by Alessandrini et al. (2009) that takes into account the distance of local branches from their own headquarters. This measure of functional distance is challenging the view that it is a characteristic that banks either have or do not have, regardless of their location. Instead, we suggest that all banks are subject to organizational issues then we propose a continuous measure of local banking structure.

\section{Data and variables}

\subsection{Dataset}

To test the effects of spatial diffusion-concentration on SME lending, we build up a panel dataset containing information on firms, bank branches, head office locations, and macro variables in France at the departmental level. The time period considered ranges from $2001-2008$. After cleaning, we have around 11000 observations.

The dataset relies on four main sources. SME specific information is drawn from a well known database DIANE ${ }^{4}$. We consider French manufacturing enterprises with 1-500 employees from which we exclude those who are subsidiaries of groups because of their financial dependence of the group. We randomly selected and stratified firms by size (four classes of employees), technology-intensive industry (four classes according to the $\mathrm{SESSI}^{5}$ classification) and geographical area (six mega regions).

In general, we eliminated observations in the extreme percentiles of the distribution of profit ratios. We did the same for observations showing an accumulation rate above $150 \%$

${ }^{4}$ DIANE: DIsque pour l'ANalyse Economique, edited by the Bureau van Dijk.

5 SESSI: Service of industry studies and statistics. Ministry of Economy, Finance and Industry (France). 
and a tripling of sales in order to avoid retaining in the sample firms that have undergone major restructuring.

Data on geographical distribution at the departmental level of all bank branches are from the banks' location files of the Bank of France. Information on the composition of banking groups and the location of bank head offices is from banks annual reports. We obtain the geographical location of all head offices and their changes over time generated by intra group consolidations (especially for mutual and savings bank groups) by tracking the groups' annual reports. The number of workers employed by sector $s$ in department $d$ is from Unedic statistics and macroeconomic data on sectorial deflators of industry output and nominal investment and data on the population at the departmental level is from the National Institute of Statistics and Economic Studies (INSEE). Appendix B defines the variables employed in the empirical specifications and provides their mean, median, standard deviation and sources.

\subsection{Distances}

\subsubsection{The banking system operational proximity}

The notion of operational distance is the one usually examined in the banking literature. It is conceivable to assume that the number of bank branches in a giving geographical area (here the department) is typically positively related to the operational proximity $(O P)$ of the banking system to this area. To measure this notion, we build up the most widely used index of bank presence in an area (Bonaccorsi di Patti and Gobbi, 2001; Bonaccorsi di Patti, 2003; Benfratello et al., 2008; Alessandrini et al., 2009), which allows us to easily compare our results with literature. It is a branch density index in terms of population:

$$
O P_{-} P O P_{d}=\frac{\sum_{b=1}^{b_{d}} \text { Branch number }_{b}}{\text { Population }_{d}} * 10000
$$

where $b_{d}$ is the total number of banks operating in the department $d(d=1, \ldots, 96)$

Of course, one can argue that this measure may be a better proxy for competition than for proximity. This is a problem as the literature indicated different outcomes for proximity and competition on credit availability. It is probably not the case because two departments having the same degree of competition may show different number of branches and thus different degree of proximity. For example, two departments with equal number of banks (equal degree of competition) may show very different operational proximity. In this respect, it is worth noting that $O P_{-} P O P_{d}$ is only slightly correlated with the departmental Herfindahl-Hirschman concentration index $H H I$ (see Table 1), suggesting that operational proximity and competition are two different elements. 
Table 1: Pairwise Correlation Matrix

\begin{tabular}{lccccccc}
\hline & $I / K$ & $C F / K$ & $F D_{-} K M$ & $F D_{-} E C O$ & $O_{-} P O P$ & $\Delta y$ & $H H I$ \\
$I / K$ & 1 & & & & & & \\
$C F / K$ & $0.2428^{* * *}$ & 1 & & & & & \\
$F D_{-} K M$ & $-0.0131^{*}$ & $-0.0904^{* * *}$ & 1 & & & & \\
$F D_{-} E C O$ & -0.0114 & $-0.0452^{* * *}$ & $0.5637^{* * *}$ & 1 & & & \\
$O P_{-} P O P$ & -0.0032 & $0.0232^{* * *}$ & $-0.1481^{* * *}$ & $-0.3930^{* * *}$ & 1 & & \\
$\Delta y$ & $0.1348^{* * *}$ & $0.1657^{* * *}$ & 0.0019 & -0.0123 & -0.0071 & 1 & \\
$H H I$ & $0.0217^{* * *}$ & $-0.0934^{* * *}$ & $0.3616^{* * *}$ & $0.1665^{* * *}$ & $0.1301^{* * *}$ & 0.0006 & 1 \\
\hline
\end{tabular}

$* * *, * *, *$ significant at the $1 \%, 5 \%$ and $10 \%$ levels respectively

\subsubsection{The banking system functional distance}

Functional proximity is usually measured as the proportion of local credit market (in terms of branches or deposits) controlled by banks that concentrate their activities in a delimited area. This measure implicitly assumes that functional distance is a dichotomous character that concerns only some, usually small, mutual and cooperative, banks and not the others. According to Alessandrini et al. (2009), functional distance is 'a character shared to some extent by all banks that, given the localism of their decisional centres and strategic functions, are necessarily close to some areas and far from others'. To this respect, while a department with banking system formed by only local credit banks has the lowest value of functional distance indicators; it is also true that two departments with equally functionally distant banking systems may show very different proportion of local banks.

We adopt measures of functional distance at the departmental level advanced by Alessandrini et al. (2009). We compute the functional distance of the banking system from department $d$ by weighting the proportion of each bank branches operating in the department $d$ by the distance indicator that captures the severity of information asymmetries between the senior manager at the parent bank and the bank officer at the local branch. Organizational frictions induced by these information asymmetries are considered positively correlated to the distance between the bank's headquarter and the local lending office.

We build up two alternative functional distance indexes. The first one is:

$$
F D_{-} K M_{d}=\sum_{b=1}^{b d}\left[\frac{\text { Branch number }_{b}}{\sum_{b=1}^{b d} \text { Branch number }_{b}} * \operatorname{Ln}\left(1+\text { Physical distance }_{d h}\right)\right]
$$

The physical distance is the kilometric orthodromic ${ }^{6}$ distance between the local capital town (also called a prefecture) of the department $d$ in which the branch is located

\footnotetext{
${ }^{6}$ Also called 'as the crow flies distance' or 'great-circle distance' and defined as the shortest distance between any two points of a sphere.
} 
and the local capital town of the department $h(\mathrm{~h}=1, \ldots, 96)$ where the head office of the own (parent) bank is headquartered (Physical distance ${ }_{d d}=0$ when a bank branch and its head office are in the same department $d$ ).

The second indicator of function distance is:

$$
F D_{-} E C O_{d}=\sum_{b=1}^{b d}\left[\frac{\text { Branchnumber }_{b}}{\sum_{b=1}^{b d} \text { Branch number }_{b}} * \operatorname{Ln}\left(1+\text { Economic gap }_{d h}\right)\right]
$$

The economic gap (or distance) measured as $\sum_{s=1}^{m}\left|E_{s d}-E_{s h}\right|$ is an index of the economic structure difference between departments $d$ and $h$ computed using shares of workers $E$ employed by $m$ economic sectors. The idea behind the use of this indicator of functional distance is that as differences increase in the economic structure of the departments where the parent bank and local branch are located, so does the informational rent of local loan officers who can accumulate specific knowledge on the local economy.

Functional distance indexes are positively and significantly correlated with one another and uncorrelated with operational proximity indexes. This corroborates the idea that functional distance includes physical and economic distances.

\subsection{Measuring credit constraints}

It is difficult to directly measure financial constraints that prevent firms from investing as much as they wish. Problems of information asymmetry related to the quality of investment projects and the management competence of the business owner are mainly what may interfere with the functioning of financial markets (Stiglitz and Weiss, 1981; Myers and Majluf, 1984). These problems imply that in general, firms use primarily internal resources to finance their investments before turning to external financing sources and especially to traditional bank financing. This is the case for French SMEs (as shown by Appendix C).

The elusiveness of the notion of credit constraints makes it hard to measure. In fact, what we generally observe in the firms balance-sheets is the quantity of loan made, not the amount requested and the amount granted. Therefore, many proxy variables where proposed in the literature.

The proxy of financing constraints used in this paper is drawn from the large strand of literature which investigates the sensitivity of firm's investment to the cash flow ${ }^{7}$ (Fazzari et al., 1988; Kaplan and Zingales, 1997). Fazzari et al. (1988) classify firms according to whether they were likely to be financially constrained on the basis of their size, dividend payouts and capital structure. These characteristics determine whether they are more sensitive to the supply of internal funds measured by cash flow. The highest sensitivities

\footnotetext{
${ }^{7}$ Other proxies for credit rationing are those of Kugler (1987) and King (1986) that attempt to estimate equilibrium credit rationing. Clearly (1999) uses multiple discriminant analysis to identify firms with financing constraints.
} 
to cash flow are found for firms classified as financially constrained. Many further studies have followed the same methodology including Chirinko and Schaller (1995), Hubbard et al. (1995), Calomaris and Hubbard (1995), as summarized by Hubbard (1998).

\subsection{Descriptive statistics}

Figures 1 and 3 show a significant increase (on average) of both operational proximity (from 4.201 branches per 10000 inhabitants in 2001 to 4.378 branches per 10000 inhabitants in 2008) and functional distance (from around $27 \mathrm{~km}$ in 2001 to around $34 \mathrm{~km}$ in 2008) of the banking system to French departments. As a matter of fact, it is worth noting that functional distance has increased at higher pace than operational proximity showing that the trend toward the internal grouping of mutual networks is stronger than the recent process of banking supply system reinforcement. Table 2 shows that operational and functional distances measures have both a greater variability across departments (between variation) than over time (within variation). The regional distribution of distance indicators in 2008 shows that the banking system is operationally more proximate to the East, West, and Center than to the North and South (see Figures 2 and 4). It is functionally more distant to the East, Center, North, and South than to the West. However, it is interesting to mention that the $2001-2008$ regional operational proximity growth rate is the highest in the North and in the South, and that the functional distance growth rate is the highest in the West, Center and East.

Table 2: Banking distance variables: summary statistics

\begin{tabular}{lcccccc}
\hline \multirow{2}{*}{ Year } & \multicolumn{2}{c}{ FD_KM } & \multicolumn{2}{c}{ FD_ECO } & \multicolumn{2}{c}{ OP_POP } \\
\cline { 2 - 6 } $\mathbf{2 0 0 1}$ & Mean & Std. Dev. & Mean & Std. Dev. & Mean & Std. Dev. \\
$\mathbf{2 0 0 2}$ & 3.320 & 1.133 & 0.230 & 0.094 & 4.210 & 0.891 \\
$\mathbf{2 0 0 3}$ & 3.361 & 1.145 & 0.230 & 0.091 & 4.205 & 0.874 \\
$\mathbf{2 0 0 4}$ & 3.402 & 1.121 & 0.230 & 0.089 & 4.197 & 0.786 \\
$\mathbf{2 0 0 5}$ & 3.422 & 1.116 & 0.230 & 0.088 & 4.243 & 0.772 \\
$\mathbf{2 0 0 6}$ & 3.438 & 1.115 & 0.229 & 0.088 & 4.308 & 0.769 \\
$\mathbf{2 0 0 7}$ & 3.462 & 1.112 & 0.240 & 0.089 & 4.343 & 0.766 \\
$\mathbf{2 0 0 8}$ & 3.496 & 1.156 & 0.232 & 0.099 & 4.347 & 0.752 \\
\hline
\end{tabular}


Salima Djedidi Kooli

$2001-2008$ Growth rates

\begin{tabular}{|c|c|c|c|}
\hline France & $7.26 \%$ & $6.61 \%$ & $4 \%$ \\
\hline North & $3.55 \%$ & $3.64 \%$ & $6.59 \%$ \\
\hline West & $12.27 \%$ & $10.21 \%$ & $-1.56 \%$ \\
\hline Centre & $12.08 \%$ & $7.92 \%$ & $0.28 \%$ \\
\hline East & $11.91 \%$ & $6.45 \%$ & $2.20 \%$ \\
\hline South West & $3.96 \%$ & $1.65 \%$ & $6.34 \%$ \\
\hline South East & $2.35 \%$ & $-1.24 \%$ & $7.01 \%$ \\
\hline \multicolumn{4}{|c|}{ Overall, Between and Within variations (across departments) } \\
\hline Overall & 1.141 & 0.092 & 0.796 \\
\hline Between & 1.118 & 0.090 & 0.777 \\
\hline Within & 0.226 & 0.016 & 0.172 \\
\hline
\end{tabular}

Note: The table reports the summary statistics for the banking distance variables (defined above). In the last part of the table, we report the overall, within and between variations of these variables across departments. 
Figure 1: Evolution of the operational proximity by region, $2001-2008$.

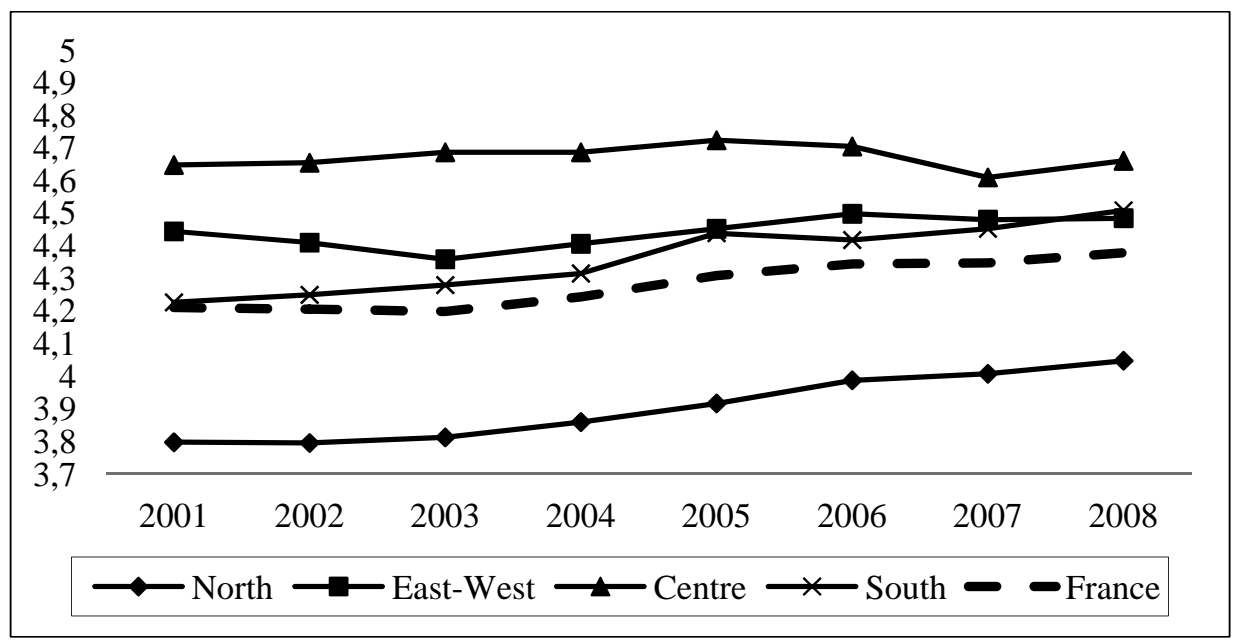

Figure 2: Operational proximity in the 96 French departments, 2008

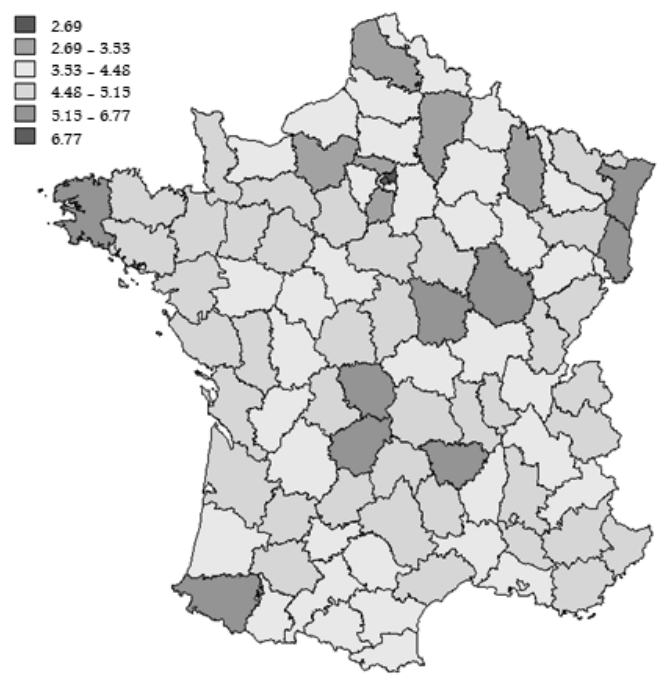


Figure 3: Evolution of the physical functional distance by region, $2001-2008$

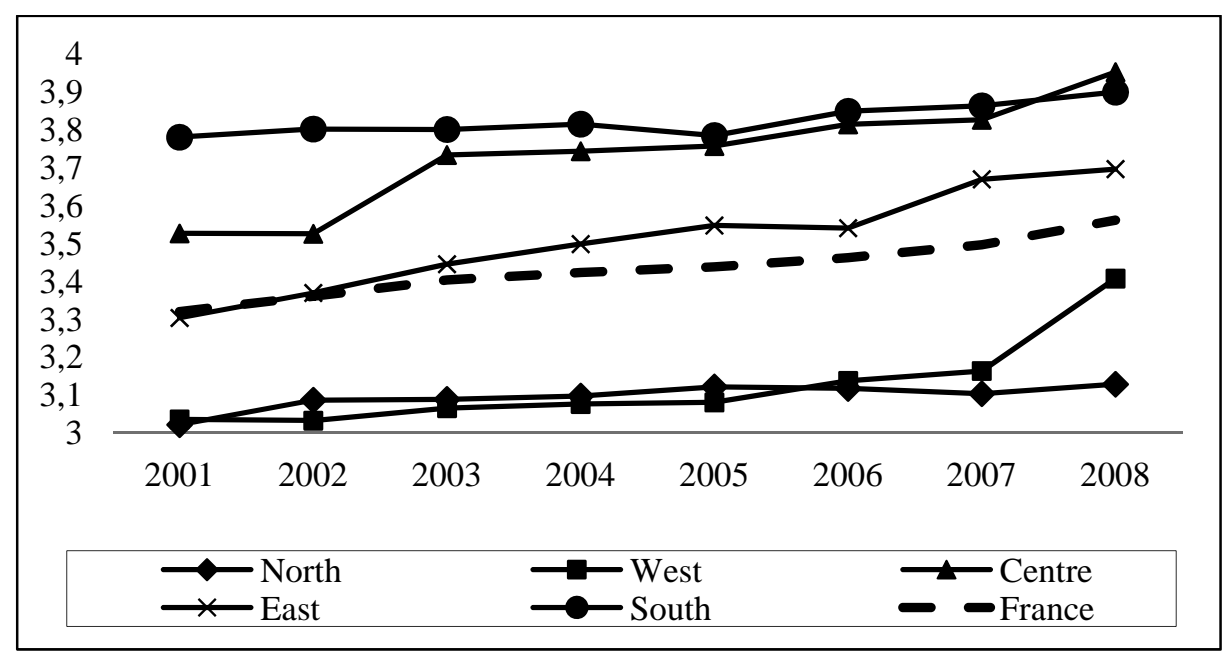

Figure 4: Physical functional distance in the 96 French departments, 2008
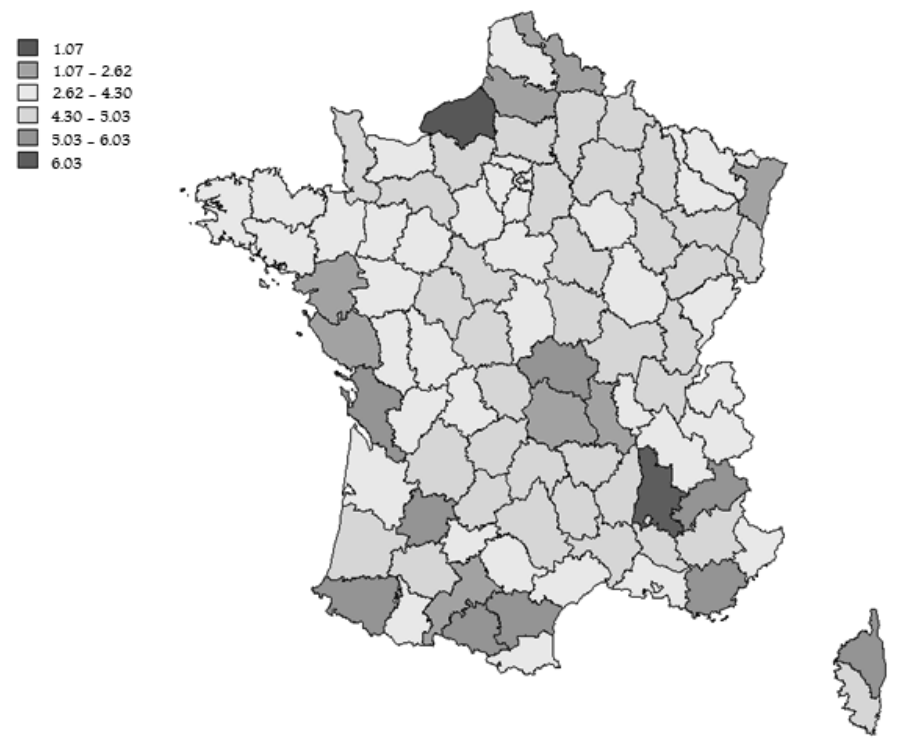


\section{The empirical strategy}

\subsection{A profit-accelerator investment model}

We first model the optimal firm demand of capital based on the neoclassical theory of investment as it was presented by Jorgenson (1963). The intertemporal maximization of the firm value leads to the optimal capital stock by equalizing its marginal productivity value with its user cost. Accordingly, under the assumption of a firm taking prices as given on a perfectly competitive market or facing a constant price elasticity function of good demand in a market of imperfect competition and assuming that the firm has a constant elasticity of substitution production function and no adjustment costs, the optimal capital stock is proportional to output,

$$
k_{i t}=\theta y_{i t}+h_{i t}
$$

with $k_{i t}$ and $y_{i t}$ the log of optimal capital stock and the log of output. $h_{i t}$ is a function of the user cost. The introduction of adjustment costs results in a gradual adjustment of capital stock to its optimal value (Hall and Jorgenson, 1971). Modelling the adjustment process between $k_{i t}$ and $y_{i t}$ requires the incorporation of a long run relationship between capital and sales in an autoregressive distributed lag model $(2,2)$ with two lags for the capital and two lags for sales. This specification seems sufficient flexible yet parsimonious because it introduces an autoregressive process on $k_{i t}$ to take into account the adjustment dynamic. In the estimates, the variation of $h_{i t}$, that includes the user cost, the capital depreciation for each firm and the productivity term, is taken into account by the fixed effects specific to firms $\mu_{i}$ and a set for time dummies $\vartheta_{t}$. Thus, we obtain the following linear regression:

$$
k_{i t}=\mu_{i}+\vartheta_{t}+\gamma_{1} k_{i t-1}+\gamma_{2} k_{i t-2}+\beta_{0} y_{i t}+\beta_{1} y_{i t-1}+\beta_{2} y_{i t-2}+\varepsilon_{i t}
$$

with $\varepsilon_{i t}$ the random error term of the regression. Instead of directly estimate this regression (4.2) (which could pose a problem because of strong collinearity between variables), we rewrite it in an error correction format adopted in several recent studies (Bond et al., 2003; Bond et al., 2005; Mairesse et al., 2001; Mizen and Vermeulen, 2005).

$$
\begin{aligned}
\Delta k_{i t}=\mu_{i}+\vartheta_{t} & +\left(\gamma_{1}-1\right) \Delta k_{i t-1}+\beta_{0} \Delta y_{i t}+\left(\beta_{0}+\beta_{1}\right) \Delta y_{i t-1} \\
& +\left(\gamma_{1}+\gamma_{2}-1\right)\left(k_{i t-2}-y_{i t-2}\right)+\left(\beta_{0}+\beta_{1}+\beta_{2}+\gamma_{1}+\gamma_{2}-1\right) y_{i t-2}+\varepsilon_{i t}
\end{aligned}
$$

Thus, we obtain a relation linking current growth rates of capital stock and sales with those of the previous period and evolving the error correction term, i.e. the gap between the current capital stock and the optimal capital stock, and a scale factor.

The importance of financial constraints in this model can be ascertained by including the profit rate, measured as the cash flow scaled by capital, to the relation (3), as a measure of the supply of internal funds in the regression. Since the aim of the paper is to test the effects of operational proximity and functional distance on the sensitiveness of firm investment to cash flow, we interact cash flow with operational proximity, squared operational proximity 
and functional distance indicators. The idea behind these interaction terms is that we make the investment-cash flow sensitivity a non linear function of $O P$ but linearly related to $F D$. In fact, this measure of the supply of internal funds becomes:

$$
\frac{\partial\left(\frac{I}{K}\right)}{\partial\left(\frac{C F}{K}\right)}=\mu_{0}+\mu_{1} O P+\mu_{2} O P^{2}+\mu_{3} F D
$$

Then, by assuming that the change in the capital stock can be approximated by investment over previous capital stock less depreciation ${ }^{8}, \Delta k_{i t} \approx \frac{I_{i, t}}{K_{i t-1}}-\delta$, we can rewrite
the regression (3) in panel data format:

$$
\begin{aligned}
& \left(\frac{I_{t}}{K_{t-1}}\right)_{i d}=\mu_{i}+\vartheta_{t}+\eta_{1}\left(\frac{I_{t-1}}{K_{t-2}}\right)_{i d}+\zeta_{0} \Delta y_{i d t}+\zeta_{1} \Delta y_{i d t-1}+\lambda\left(k_{i t-2}-y_{i t-2}\right)+\rho y_{i t-2}+\mu_{0}\left(\frac{C F_{t}}{K_{t-1}}\right)_{i d} \\
& +\mu_{1}\left(\frac{C F_{t}}{K_{t-1}}\right)_{i d} \times O P_{-} P O P_{d t}+\mu_{2}\left(\frac{C F_{t}}{K_{t-1}}\right)_{i d} \times O P_{-} P O P_{d t}^{2}+\mu_{3}\left(\frac{C F_{t}}{K_{t-1}}\right)_{i d} \times F D_{d t}+\varepsilon_{i t}
\end{aligned}
$$

Geographic and technological intensity industry classification dummies are included in the basic specification of equation (5) to control for other unobserved local fixed effects.

In this specification, the parameter would be negative or near zero because we generally have negative autocorrelation between capital stock growth rates of two successive periods when using individual firm data. The long-run properties of this specification solely depend on the coefficient of the error correction $\lambda=\gamma_{1}+\gamma_{2}-1$ and the scale factor $\rho=\beta_{0}+\beta_{1}+\beta_{2}+\gamma_{1}+\gamma_{2}-1$. It is expected that $\lambda$ is negative because when the level of existing stock of capital is above the optimal stock (as determined by sales), there should be a reduction in the capital accumulation rate and conversely, if less, an increase. We also expect that $\mu_{0}>0$ which suppose that French SMEs are financially constrained.

Following Hauswald and Marquez (2006), we expect that

H1: the relationship between operational proximity and financing constraints is non monotone with an investment-cash flow sensitivity supposed to be increasing for low levels of OP below a certain threshold and decreasing for high levels of OP above the same threshold.

This implies a positive $\mu_{1}$ and a negative $\mu_{2}$.

Following the theoretical literature on the impact of functional distance on financing constraints described above, we expect that:

\footnotetext{
${ }^{8}$ We assume that the capital stock rate of depreciation is taken into account by the individual effects and time dummies $\mu_{i}$ and $\vartheta_{t}$.
} 
H2: the increase of the functional distance induces an increase of the investment cash flow sensitivity.

This implies a positive $\mu_{3}$.

Giving that smaller firms are more likely to be rationed than greater ones, it is interesting to verify that:

H3: the investment-cash flow sensitivity is lower for large firms comparing to small firms which are supposed to be more financially constrained.

H4: the functional distances affect differently small and large firm's investment sensitivities to cash flows.

To do this, we run two other specifications by interacting firm size with $\left(\frac{C F_{t}}{K_{t-1}}\right) * F D$.

\subsection{Estimation methodology}

The dynamic structure of the model by the inclusion of a lagged dependent variable makes usual estimators of fixed effect panel data biased and inconsistent (Verbeek, 2012; Wooldridge, 2010). By construction, the correlation between the lagged dependent variable and the error component renders the OLS estimator biased and inconsistent even if the $\varepsilon_{i t}$ are not serially correlated (Sevestre and Trognon, 1985). For the fixed effects (FE) estimator, the Within transformation wipes out the fixed effects but the correlation still persists between the transformed lagged dependent variable and errors, even if the $\varepsilon_{i t}$ are not serially correlated (Nickell, 1981). It is well known that only if $T \rightarrow \infty$ will the Within estimator of the autoregressive parameter be consistent for the dynamic error component model, which is not the case.

An alternative to the Within estimator consists on applying OLS to the model written in first differences. In this case, correlation between the predetermined explanatory variables and the reminder error is easier to handle. This solution is less satisfactory because unlike Within estimator, the first differences (FD) estimator is biased and inconsistent even when $\mathrm{N}$ and $\mathrm{T}$ both tend to infinity.

The instrumental variable (IV) estimation methods (Anderson and Hsiao, 1981) are known to have better performances than these usual methods. They lead to consistent but not necessarily efficient estimates of the parameters in the model because it suffers from a significant loss of degrees of freedom, and it does not take into account the differenced structure on the residual disturbances.

Arellano and Bond were the first in 1991 to propose an extension of the Generalized Method of Moments (GMM) in case of panel data. Their estimator were designed to avoid two causes of inefficiency of Anderson and Hsiao estimator namely the small number of instruments and the lack of consideration of the autocorrelation disturbance. From the model in first differences, Arellano and Bond (1991) note that the lagged dependent 
variable can be considered as an instrument when the $\varepsilon_{i t}$ are not serially correlated. In this case, orthogonality conditions are:

$$
E\left(y_{i t-j} \Delta \varepsilon_{i t}\right)=0 \quad \text { for } \quad t=2, \ldots, T \text { and } j=2, \ldots, T
$$

However, the Arellano and Bond (1991) estimator suffers from the loss of information associated with the first differences model which often leads to imprecise and erratic estimates.

For all these reasons, we decide to use the system-GMM (Blundell and Bond, 1998) that is known to be more efficient than the Arellano and Bond (1991) estimator. The Blundell and Bond (1998) GMM method is based on the estimation of a system of two simultaneous equations, one in levels (with lagged first differences as instruments) and the other in first differences (with lagged levels as instruments). This method has the advantage of adding other orthogonality conditions $E\left(\Delta y_{i t-j} \varepsilon_{i t}\right)=0$ for $t=2, \ldots, T$ and $j=2, \ldots, T$ in order to obtain an estimator with greater accuracy. Indeed, Blundell and Bond (1998) show, using Monte-Carlo simulations, that the use of this double set of instruments improves the estimates' quality (Roodman, 2009).

\subsection{Results}

Table 3 displays the estimation results of the basic and augmented specifications. As expected, we find that the coefficient related to the first lagged accumulation ratio is negative and significant, which is consistent with the idea that there is less incentive to currently invest in fixed capital for a firm that invested last year. Another interesting finding is the negative and significant coefficient related to the error correction term, showing that the error correction is playing in the 'right way' by reducing the capital accumulation rate when the level of existing stock of capital is above the optimal stock and by increasing the accumulation rate when the opposite occurs. We also find positive and significant effects of current and lagged sales growth rates on the accumulation rate, highlighting the importance of the accelerator effect. In fact, rising sales growth rate implies that profit expectations and business confidence rise, encouraging businesses to build more factories and other buildings and to install more machinery.

On the whole and regarding the interest variables, the results on the sensitivity of investment to cash flow are consistent with those on credit constraints described in section 2. Investment of firms in departments with a functionally more distant banking system is more sensitive to cash flow, and this effect decreases with size. All specifications display a positive coefficient on the interaction term $(C F / K) * F D$ showing that the marginal effect of cash flows on investment is increasing with the physical distance and the economic gap between the branch and the parent bank departments. These findings confirm the idea that the severity of communication and incentive problems as well as their negative impact on lending policies and credit allocation grows with the distance between bank's hierarchical levels (Alessandrini et al., 2009). 
We also consider a possible direct effect of functional distance on investment by introducing $F D$ as an isolated term in eq. (5) (see Table 3, specifications (2), (4), (6) and (8)). Nevertheless, they appear to be statistically insignificant without affecting the other estimation coefficients 9 . This finding shows that the effect of functional distance on the capital accumulation behavior is indirect. In fact, $F D$ impacts access conditions to external financing that, in turn, affects the amount invested. Thus, as Benfratello et al. (2008) and Alessandrini et al. (2009), we prefer to concentrate on the indirect effect of distance on firms' investment through its impact on financing constraints.

The results of the augmented specification (columns (6), (7), (8) and (9)) point out significant differences in the impact of functional distance on investment-cash flow sensitivity according to firm size. From column (6), we can see that the larger is the firm, the lower is the contribution of $F D \_K M$ to the marginal effect of cash flow on investment. This relation is significant for all firm size groups. In fact, the effect for the fourth size class (251 - 500 workers) is significantly lower than that of the benchmark case, constituted by the smallest group $(01-09$ workers). This trend is also confirmed for the other measure of functional distance in economic terms even if for this case the effect seems to be more pronounced. These findings are broadly consistent with the theoretical prediction stipulating that larger firms suffer less from the lack of banks' decisional centres in the department where they are located. The declining impact of functional distance on investment cash flow sensitivity according to the firm size group is reflected in the measure of elasticities of investment to cash flow according to size, as shown by the last part of Table 3 . It is interesting to note that the capital accumulation behavior is very elastic to firm liquidity (internal financing) and this is even more important than the firm size is low. We can also note that the effect of size is the same for the third and the fourth size classes suggesting that for companies with more than 250 employees, the negative impact of functional distance is rather the same.

With regard to operational proximity, our findings are consistent with the theoretical prediction advanced by Hauswald and Marquez (2006). In fact, we find that the relationship between operational proximity and financing constraints is significantly non monotone with an investment cash flow sensitivity supposed to be increasing with operational proximity for low levels of $O O_{-} P O P$ and decreasing for high levels of it. More explicitly, for values of operational proximity below the value of 4.74 or $4.68^{10}$, corresponding approximately to the $75^{\text {th }}$ percentile of the $O P \_P O P$ distribution, the probability that the lending bank is located near the firm is low, the credit screen quality is relatively uninformative and thus adverse selection problems are high (see Figure 5). This intensification of adverse selection problems due to low operational proximity generates an aggravation of firm external financing conditions and thus an increase of the investment cash flow sensitivity. However, for values of operational proximity beyond this threshold, the probability that the lending bank is located near the firm is high, the credit screen quality is sufficiently high and thus adverse selection problems are low.

\footnotetext{
9 see Table 3 and compare specifications (2) vs (3), (4) vs (5), (6) vs (7) and (8) vs (9).

10 Respectively from specifications (3) and (5)
} 
The consistencies of these results are confirmed by the validation of the instrument set at $5 \%$ and the reject of serial correlation in the original error, as desired (see Appendix D for more details). The dummies are generally not significant, except for dummies relatives to 2001 and 2002 years that shows positive and significant coefficients, except for industry dummies which shows significantly higher investment capabilities for low and medium technological sectors.

Figure 5: Illustration of the relationship between the investment cash flow sensitivity and the operational proximity

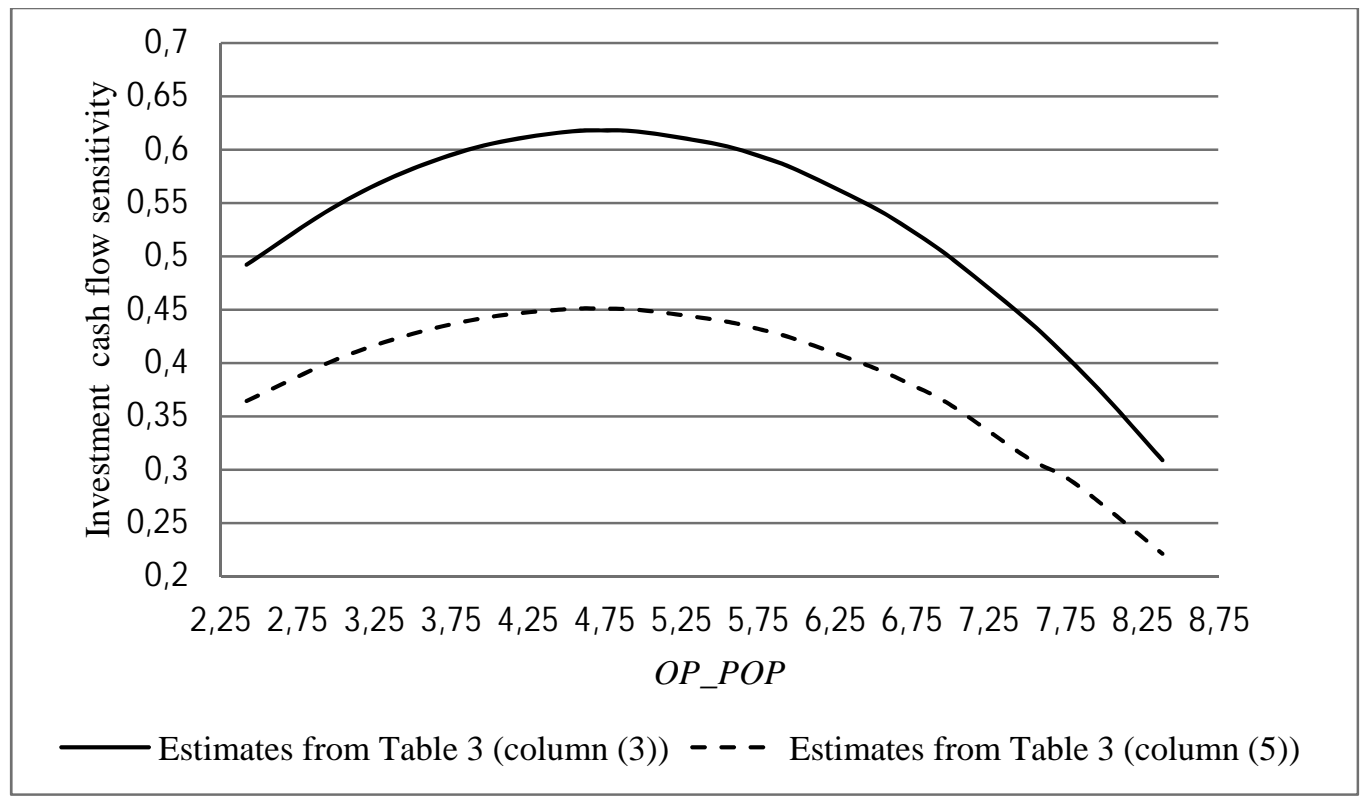

Note: Calculations are based on estimates from Table 3. The vertical blue lines demarcate the $5^{\text {th }}$ and the $95^{\text {th }}$ percentile of the $O P_{-} P O P$ distribution of the SME sample over the study period 2001 -2008 . 


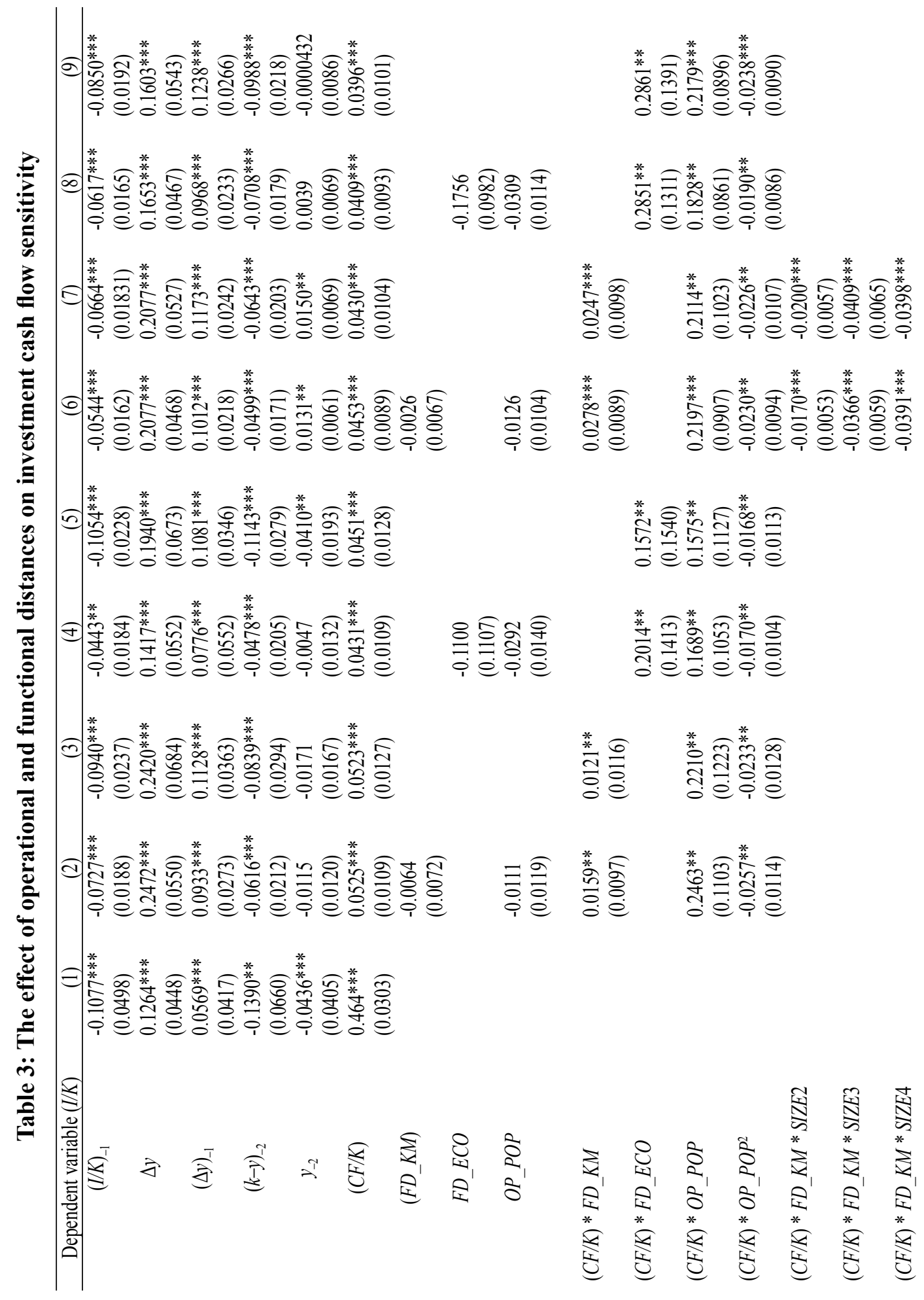




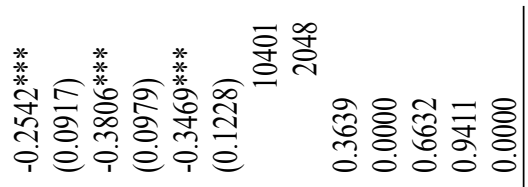

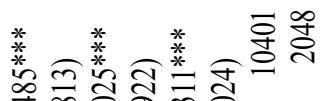

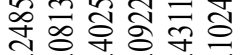

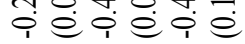

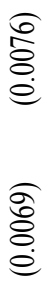

$\stackrel{\circ}{\circ} \stackrel{8}{=}$

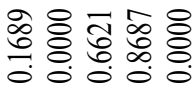

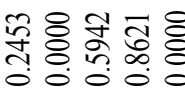

훙

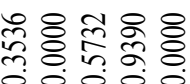

$\stackrel{2}{\circ} \stackrel{2}{\sim}$

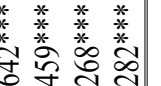

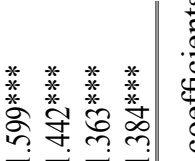

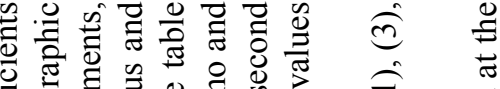

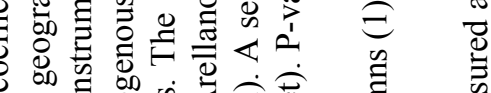

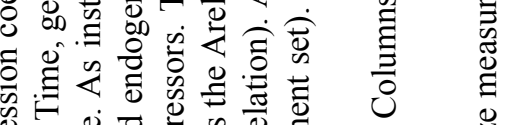

औ

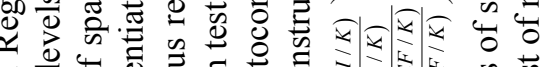

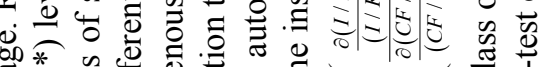

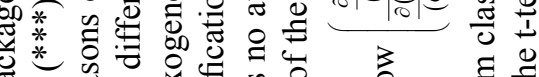

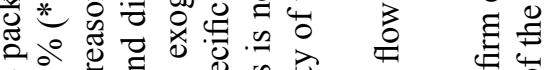

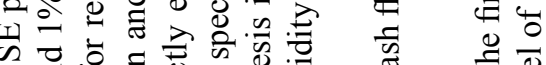

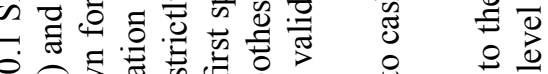

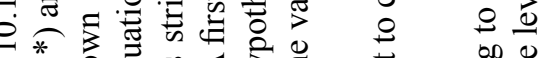

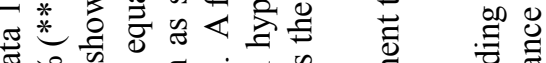

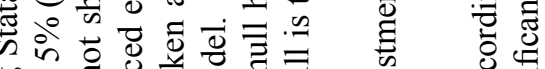

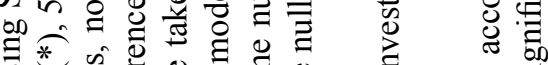

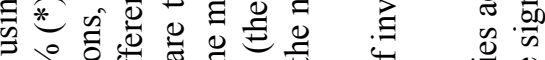

๙ิ응

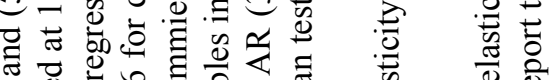

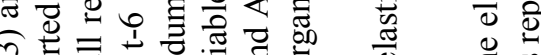

(2)

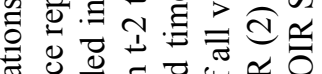

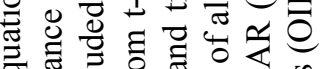

ठ

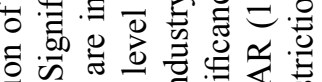

के

चं 0.50

के 형

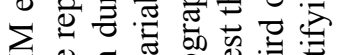

$\sum_{i} 0.000$

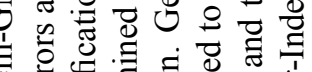

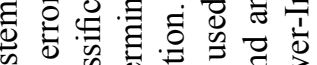

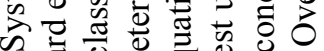

高亲

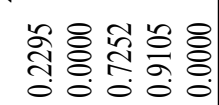

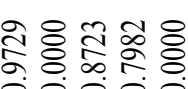

(2)

?.

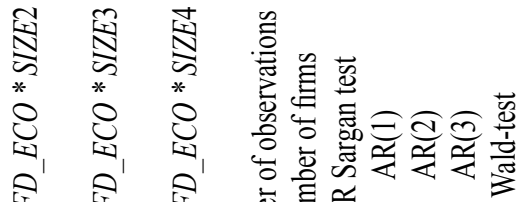

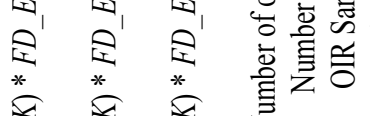

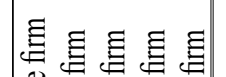

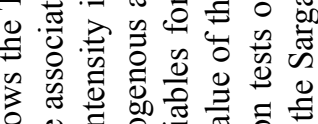

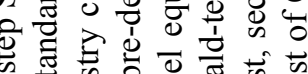

क क ज

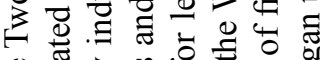

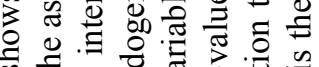

के

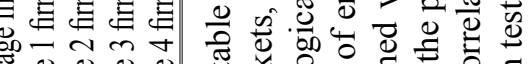

造语旅

政

章

률

ఠิ

ส

Eह

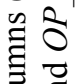

킁

Ð

4

告

西居

萦 要

$\stackrel{0}{\square}$

की

这过

它

$\circ \stackrel{0}{2}$

牙

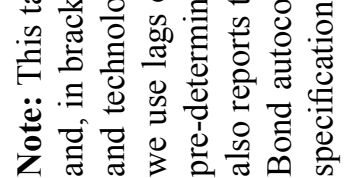

呐

(요 


\section{Conclusion}

In this paper, we have tried to assess the impact of geographical diffusion of banking structures and instruments as well as geographical concentration of decisional and strategic centres of banking institutions over the period 2001 - 2008 on firms' financing constraints. Our econometric exercise consistently show that increased functional distance made financing constraints more binding, as indicated by the positive coefficient relying it with the investment cash-flow sensitivity. Interestingly, with regard to operational proximity, our findings are consistent with the theoretical prediction of non linearity of the operational proximity with financing constraints advanced by Hauswald and Marquez (2006). This finding confirms the informational capture that an operationally close banking system may exercise on local borrowers as well as adverse selection problems arising when approaching these locally captured firms.

There are two policy-oriented implications of our findings. First, the consolidation of the French banking industry, leading to an increase of the functional distance may aggravate financing problems of small local firms, especially in peripheral departments. As Alessandrini et al. (2009) and before Berger and Udell (2006) have pointed out, these negative externalities of market deregulation could be reduced by 'favoring a change in emphasis in bank organization from the search of economies of scale by standardized, arm's-length lending technologies, to economies of scope by making specialized credit instruments available to local firms'. Second, our findings regarding operational proximity and its impact on SME financing suggest that the French banking system should be more operationally proximate to local firms to better fit their funding needs and to promote the entry and creation of new banks and non-bank competitors struggling to offer financing to local firms. Despite commendable efforts made by certain banking groups since the early 2000s to reinforce the French banking system's supply by opening new branches, much remains to be done in this field.

Finally, our results are particularly suggestive of the persistent importance of relationship lending for small opaque borrowers despite the technological progress that significantly expands the ability of banks to produce hard information and therefore substitute transactions-based lending for relationship lending and basel II recommendations that push banks to develop sophisticated credit scoring models, largely based on hard information, to assess the credit risk.

Acknowledgments I am grateful to Didier Fichaux and Loïc Dorléans (Bank of France) for providing us the banks' location files (FIB) that allows us to build up our interest variables. For useful comments, I thank François Etner, Alon Raviv as well as the participants at the ' $9^{\text {th }}$ International Conference of the Middle East Association' (Istanbul, June 2010), the 8th AFFI-EUROFIDAI International Paris Finance meeting (Paris, December 2010) and the IFABS conference (Rome, June-July 2011) for helpful suggestions. 


\section{References}

Agarwal, S. and Hauswald, R., 2010, 'Distance and private information in lending', Review of Financial Studies, 23, 7, pp. 2757-2788.

Alessandrini, P., Calcagnini, G. and Zazzaro, A., 2008, 'Asset restructuring strategies in bank acquisitions: Does distance between dealing partners matter?', Journal of Banking Finance, 32, 5, pp. 699-713.

Alessandrini P., Croci M. and Zazzaro, A., 2005, 'The geography of banking power: the role of functional distance', Banca Nationale del Lavoro Quarterly Review, LVIII, 235, pp. 129-67.

Alessandrini, P., Presbitero, A.F. and Zazzaro, A., 2009, 'Banks, distances and firms' financing constraints', Review of Finance, 13, 2, pp. 261-307.

Anderson, T. and Hsaio, C., 1981, 'Estimation of dynamic models with error components', Journal of American Statistical Association, 76, 375, pp. 589-606.

Ang, J.S., 1991, 'Small business uniqueness and the theory of financial management', The Journal of Small Business Finance, 1, 1, pp. 1-13.

Arellano, M. and Bond, S., 1991, 'Some tests of specification for Panel Data: Monte Carlo Evidence and an Application to Employment Equations', Review of Economic Studies, 58, 2, 277-297.

Avery, R.B. and Samolyk, K.A., 2000, 'Bank consolidation and the provision of banking services: The case of small commercial loans', FDIC Working paper 2000-01.

Benfratello, L., Schiantarelli, F. and Sembenelli, A., 2008, 'Banks and innovation: microeconometric evidence on Italian firms', Journal of Financial Economics, 90, 2, pp. 197-217.

Berger, A.N., Demsetz, R. and Strahan, P., 1999, 'The Consolidation of the Financial Services Industry: Causes, Consequences, and Implications for the Future', Journal of Banking and Finance, 23, 2-4, pp. 135-194.

Berger, A.N., Miller, N.H., Petersen, M.A., Rajan, R.G. and Stein, J.C., 2005, 'Does function follow organizational form? Evidence from the lending practices of large and small banks', Journal of Financial Economics, 76, 2, pp. 237-69.

Berger, A.N., Rosen R. and Udell G.F., 2007, 'Does market size structure affect competition? The case of small business lending', Journal of Banking and Finance, 31, 1, pp. 11-33.

Berger, A.N., Saunders, A., Scalise, J.M. and Udell, G.F., 1998, 'The effects of banks mergers and acquisitions on small business lending', Journal of Financial Economics, 50, 2, pp. 187-229.

Berger, A.N. and Udell, G.F., 1996, 'Universal Banking and the Future of Small Business Lending', Saunders, A. and Walter, I., Financial System Design: The Case of Universal Banking, Irwin, Burr Ridge, pp. 559-627.

Berger, A.N. and Udell, G.F., 1998, 'The Economics of Small Business Finance: the Role of Private Equity and Debt Markets in the Financial Growth Cycle', Journal of Banking and Finance, 22, 6-8, pp. 613-673.

Berger, A.N. and Udell, G.F., 2002, 'Small business credit availability and relationship 
lending: The importance of bank organizational structure', The Economic Journal, 112, 477, pp. F32-F53.

Blundell, R. and Bond, S., 1998, 'Initial conditions and moment restrictions in dynamic panel data models', Journal of Econometrics, 87, 1, pp. 115-143.

Bonaccorsi di Patti, E., 2003, 'Preferences in bank-firm relationships', unpublished working paper, Bank of Italy.

Bonaccorsi di Patti, E. and Gobbi, G., 2001, 'The changing structure of local credit markets: Are small business special?', Journal of Banking and Finance, 25, 12, pp. 2209-37.

Bonaccorsi di Patti, E. and Dell'Ariccia, G., 2004, 'Bank competition and firm creation', Journal of Money Credit and Banking, 36, 2, pp. 225-51.

Bond, S.R., Elston, J., Mairesse, J. and Mulkay, B., 2003, 'Financial Factors and Investment in Belgium, France, Germany and the UK: A comparison using Company Panel Data', The Review of Economics and Statistics, 85, 1, pp. 153-165.

Bond, S.R., Harhoff, D. and Van Reenen, J., 2005, 'Investment, R\&D, and Financial Constraints in Britain and Germany', Annales d'Economie et de Statistiques, 79-80, pp. 433-460.

Boot, A.W.A., 2000, 'Relationship banking: What do we know?', Journal of Financial Intermediation, 9, 1, pp. 7-25.

Calomiris, C. and Hubbard, R.G., 1995, 'Internal finance and firm-level adjustment and aggregate investment dynamics', Brookings Paper on Economic Activity, 2, pp. 1-54.

Carling, K. and Lundberg, S., 2005, 'Asymmetric information and distance: An empirical assessment of geographical credit rationing', Journal of Economics and Business, 57, 1, pp. 39-59.

Carpenter, R.E. and Petersen, B.C., 2002, 'Capital Market Imperfections, High-tech Investment and New Equity Financing', The Economic Journal, 112, 477, pp. F54-F72.

Chirinko, R. and Schaller, H., 1995, 'Why does Liquidity matter in Investment Equations', Journal of Money Credit and Banking, 27, 2, pp. 527-547.

Chittenden, F., Hall, G. and Hutchinson, P., 1996, 'Small Firm Growth, Access to Capital Market and Financial Structure: Review of Issues and an empirical Investigation', Small Business Economics, 8, 1, pp. 56-67.

Clearly, S., 1999, 'The Relationship between firm investments and financial status', Journal of Finance, 54, 2, pp. 673-692.

Collender, R.N. and Shaffer, S., 2003, 'Local bank office ownership, deposit control, market structure, and economic growth', Journal of Banking and Finance, 27, 1, pp. 27-57.

Cole, R.A., Goldberg, L.G. and White, L.J., 2004, 'Cookie-cutter versus character: the micro structure of small business lending by large and small banks', Journal of Financial and Quantitative Analysis, 39, 2, pp. 227-51.

Cole, R.A., Wolken, J. and Woodburn, L., 1996, 'Bank and non-bank competition for small business credit: Evidence from the 1987 and 1993 National Surveys of Small Business Finances', Federal Reserve Bulletin, 82, pp. 983-995.

Crémer, L., Garicano, L. and Prat, A., 2007, 'Language and the Theory of the Firm', The Quarterly Journal of Economics, 122, 1, pp. 373-407. 
De Young, R., Goldberg, L.G. and White, L.J., 1999, 'Youth, Adolescence, and Maturity of Banks: Credit Availability to Small Business in an Era of Banking Consolidation', Journal of Banking and Finance, 23, 2, pp. 463-492.

Fazzari, S.M., Hubbard, R.G. and Petersen, B.C., 1988, 'Financing constraints and corporate Investments', Brookings Paper on Economic Activity, 1, pp. 141-195.

Hall, R.E. and Jorgenson, D.W., 1971, 'Application of the Theory of Optimum Capital Accumulation', Fromm G., Tax Incentive and Capital Spending, The Bookings Institution, Washington, pp. 9-60.

Hauswald, R. and Marquez, R., 2006, 'Competition and strategic information acquisition in credit markets', Review of Financial Studies, 19, 3, pp. 967-1000.

Haynes, G.W. and Berney, R., 1999, 'Small business borrowing from large and small banks', Blanton, JL., Williams, A. and Rhine, SLW., Business Access to Capital and Credit, A Federal Reserve System Research Conference, pp. 287-327.

Holmes, S. and Kent, P., 1991, 'An Empirical Analysis of the Financial structure of Small and Large Australian Manufacturing Enterprises', The Journal of Small Business Finance, 1, 2, pp. 141-154.

Hubbard, R.G., 1998, 'Capital-Market Imperfections and Investment', Journal of Economic Literature, 36, 1, pp. 193-225.

Hubbard, R.G., Kashyap A.K. and Whited T.M., 1995, 'Internal Finance and Firm Investment', Journal of Money Credit and Banking, 27, 3, pp. 683-701.

Jayaratne, J. and Wolken, J., 1999, 'How important are small banks to small business lending? - New evidence from a survey of small firms', Journal of Banking and Finance, 23, 2-4, pp. 427-458.

Jensen, M.C. and Meckling, W.H., 1976, 'Theory of the firm: Managerial behavior, Agency costs and ownership structure', Journal of Financial Economics, 3, 4, 305-360.

Jorgenson, D.W., 1963, 'Capital Theory and Investment behavior', American Economic Review, 53, 2, pp. 247-259.

Kaplan, S.N. and Zingales, L., 1997, 'Do investment-cash flow sensitivities provide useful measures of financing constraints', Quarterly Journal of Economics, 112, 1, pp. 167215

Keeton, W.R., 1995, 'Multi-office bank lending to small businesses: some new evidence', Federal Reserve Bank Kansas City Economic Review, 80, 2, pp. 45-57.

King, S., 1986, 'Monetary transmission: Through bank loans or bank liabilities?', Journal of Money Credit and Banking, 18, 3, pp. 290-303.

Kugler, P., 1987, 'Credit rationing and the adjustment of the loan rate: an empirical investigation', Journal of Macroeconomics, 9, 4, pp. 505-525.

Liberti, J.M. and Mian A., 2009, 'Estimating the effect of hierarchies on information use', Review of Financial Studies, 22, 10, 4057-90.

Mairesse, J., Mulkay, B. and Hall, B.H., 2001, 'Investissement des entreprises et contraintes financières en France et aux Etats-Unis', Economie et statistique, 341-342, pp. 65-84.

Mizen, P. and Vermeulen, P., 2005, 'Corporate Investment and Cash flow sensitivity: What drives the Relationship?', European Central Bank Working Paper nº485, pp. 4-40. 
Myers, S. and Majluf, N.S., 1984, 'Corporate Financing and Investment Decisions when firms have information that Investors do not have', Journal of Financial Economics, 13, 2, pp. 187-221.

Nickell, S., 1981, 'Biases in Dynamic Models with fixed effects', Econometrica, 49, 6, pp. 1417-1426.

Peek, J. and Rosengren, E.S., 1996, 'Small Business Credit Availability: How important is the size of lender?', Saunders, A. and Walter, I., Universal Banking Financial System Design Reconsidered, W. Ingo. Homewood IL, Irwin Publishing, pp. 628-55

Peek, J. and Rosengren, E.S., 1998, 'Bank consolidation and small business lending. It's not just bank size that matters', Journal of Banking and Finance, 22, 6-8, pp. 799-819.

Petersen, M.A. and Rajan, R.G., 2002, 'Does distance still matter? The information revolution in small business lending', Journal of Finance, 57, 6, pp. 2533-2570.

Roodman, D., 2009, 'How to do xtabond2: An introduction to difference and system GMM in Stata', Stata Journal, 9, 1, pp. 86-136.

Sapienza, P., 2002, 'The effects of banking mergers on loan contacts', Journal of Finance, 57, 1, pp. 329-367.

Scott, J.A., 2004, 'Small business and the value of community financial institutions', Journal of Financial Services Research, 25, 2-3, pp. 207-30.

Sevestre, P. and Trognon, A., 1985, 'A note on autoregressive error components models', Journal of Econometrics, 28, 2, pp. 231-245.

Stein, J., 2002, 'Information production and capital allocation: Decentralized versus hierarchical firms', Journal of Finance, 57, 5, pp. 1891-1921.

Stiglitz, J. and Weiss, A., 1981, 'Credit rationing in markets with imperfect information', American Economic Review, 71, 3, pp. 393-410.

Strahan, P.E. and Weston, J.P., 1996, 'Small Business Lending and bank consolidation: is there cause for concern?', Current Issues in Economics and Finance, 2, 2, pp. 1-6.

Strahan, P.E. and Weston, J.P., 1998, 'Small Business Lending and the changing structure of the Banking Industry', Journal of Banking and Finance, 22, 6-8, pp. 821-845.

Uchida, H., Udell, G.F. and Watanabe, W., 2008, 'Bank size and lending relationships in Japan', Journal of Japanese and International Economies, 22, 2, pp. 242-267.

Udell, G.F., 1989, 'Loan quality, commercial loan review and loan officer contracting', Journal of Banking and Finance, 13, 3, pp. 367-382.

Verbeek M., 2012, 'A guide to modern econometrics', $4^{\text {th }}$ edition, Wiley.

Wooldridge, J., 2010, 'Econometric analysis of cross section and panel data', $2^{\text {nd }}$ edition, MIT Press. 


\section{Appendix}

\section{Appendix A: Recent changes in the French banking sector}

\section{A.1: The French banking sector consolidation}

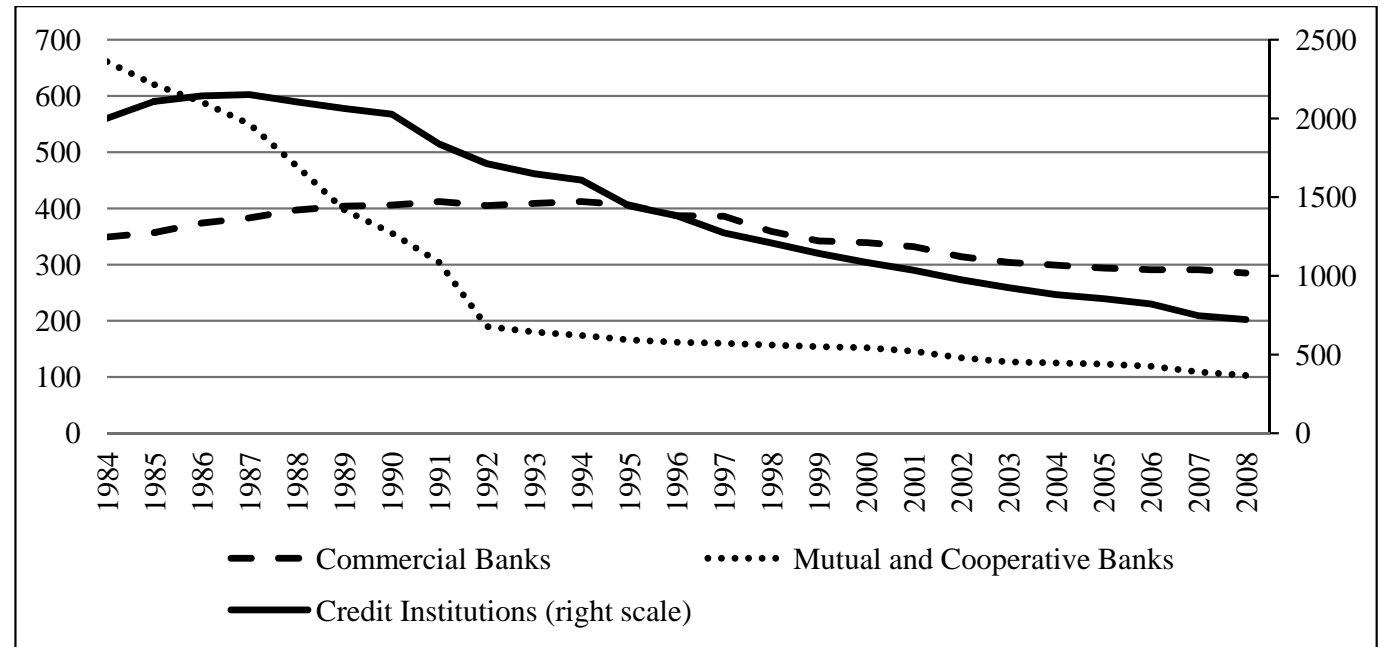

Source: CECEI annual reports and own elaboration.

\section{A.2: The emblematic internal grouping of cooperative networks}

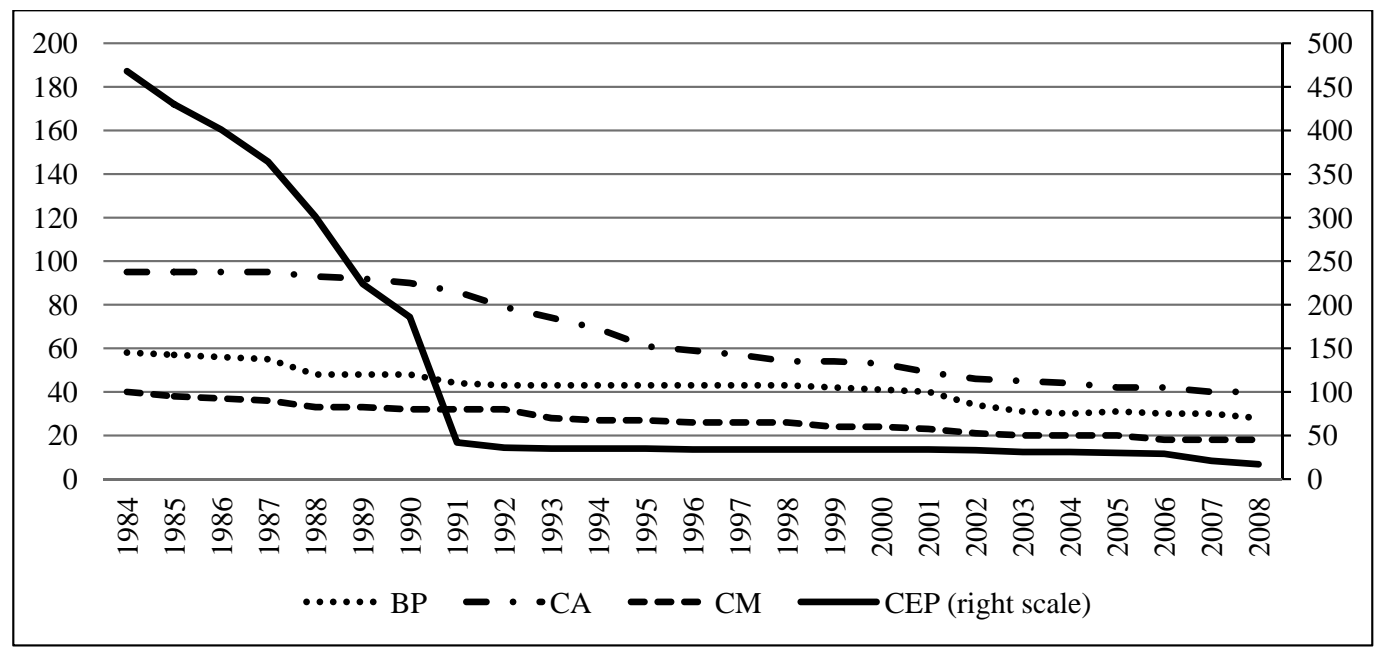

Source: CECEI annual reports and own elaboration. 


\section{A.3: Branches, ATMs and employees evolution} in the French banking system, $1999-2008$

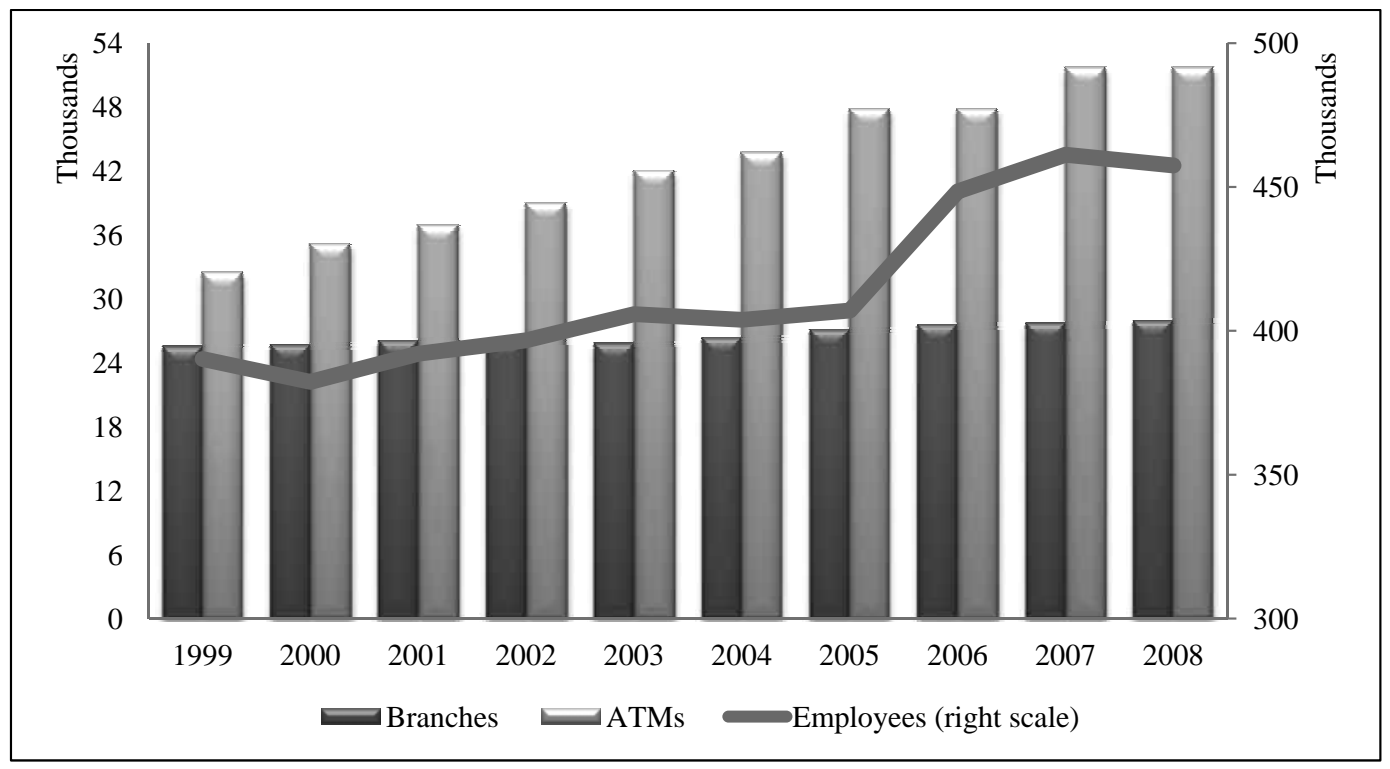

Source: CECEI annual reports and own elaboration 


\section{Appendix B: Data description}

\begin{tabular}{|c|c|c|c|c|c|c|c|}
\hline Variables & Definition & Mean & Median & Std. Dev. & Min & Max & Source \\
\hline \multicolumn{8}{|c|}{ Dependent variable } \\
\hline$(I / K)$ & $\begin{array}{l}\text { The firm-level accumulation } \\
\text { ratio. }\end{array}$ & $20.22 \%$ & $12.12 \%$ & $23.83 \%$ & 0 & $149.46 \%$ & $\begin{array}{l}\text { Author's } \\
\text { calculation } \\
\text { on Balance } \\
\text { Sheet data } \\
\text { in DIANE }\end{array}$ \\
\hline
\end{tabular}

\section{Explanatory variables}

$(C F / K)$

The firm-level ratio of profit rate. $C F$ is computed as net prof-

$53.63 \% \quad 37.78 \% \quad 52.74 \% \quad-34.09 \% \quad 295.26 \%$

it plus depreciation allowances.

$\Delta y$

The firm's annual growth rate

$2.46 \%$

$2.52 \%$

$17.93 \%$

$-69.79 \% \quad 286.67 \%$

Author's of total sales.

$(k-y) \quad$ Error correction term. It is $-1.90 \quad-1.88$ calculation on Balance Sheet data the gap between the current capital stock and the optimal capital stock.

\begin{tabular}{|c|c|c|c|c|c|c|c|}
\hline$F D_{-} K M$ & $\begin{array}{l}\text { The first measure of the or- } \\
\text { ganizational structure of the } \\
\text { local banking system. It is the } \\
\text { physical functional distance, } \\
\text { computed as the ratio of bank } \\
b \text { branches to total branches in } \\
\text { department } d \text { weighted by the } \\
\text { logarithm of } 1 \text { plus the ortho- } \\
\text { dromic distance between the } \\
\text { department of the branch and } \\
\text { the department where the par- } \\
\text { ent bank is headquartered. }\end{array}$ & 3.4473 & 3.2833 & 1.1409 & 0.647 & 6.031 & $\begin{array}{l}\text { Author's } \\
\text { calculation } \\
\text { on Bank of } \\
\text { France data } \\
\text { and Banks } \\
\text { a n n u a } 1 \\
\text { reports }\end{array}$ \\
\hline$F D_{-} E C O$ & $\begin{array}{l}\text { The second measure of the } \\
\text { organizational structure of the } \\
\text { local banking system. It is the } \\
\text { economic functional distance, } \\
\text { computed as the ratio of bank } \\
b \text { branches to total branches in } \\
\text { department } d \text { weighted by the } \\
\text { logarithm of } 1 \text { plus the index } \\
\text { of the economic structure dif- } \\
\text { ference between the depart- } \\
\text { ment of the branch and the } \\
\text { department where the parent } \\
\text { bank is headquartered in terms } \\
\text { of shares of workers employed } \\
\text { by } m \text { economic sectors. }\end{array}$ & 0.2337 & 0.214 & 0.0919 & 0.0561 & 0.5119 & $\begin{array}{l}\text { Author's } \\
\text { calculation } \\
\text { on Unedic } \\
\text { statistics } \\
\text { (UNISTA- } \\
\text { TIS) }\end{array}$ \\
\hline
\end{tabular}




\begin{tabular}{|c|c|c|c|c|c|c|c|}
\hline$O P_{-} P O P$ & $\begin{array}{l}\text { The first departmental indica- } \\
\text { tor of the local banking sys- } \\
\text { tem operational proximity to a } \\
\text { department } d \text {. It is a measure } \\
\text { of the branch density in this } \\
\text { department, computed as the } \\
\text { number of bank branches in } \\
\text { department } d \text { per } 10000 \text { in- } \\
\text { habitants. }\end{array}$ & 4.2901 & 4.2384 & 0.7959 & 2.4187 & 8.3849 & $\begin{array}{l}\text { Author's } \\
\text { calculation } \\
\text { on Bank } \\
\text { of France } \\
\text { and INSEE } \\
\text { data }\end{array}$ \\
\hline$H H I$ & $\begin{array}{l}\text { Herfindahl-Hirschman con- } \\
\text { centration index is com- } \\
\text { puted on the number of bank } \\
\text { branches in a deparment. }\end{array}$ & 0.146 & 0.148 & 0.045 & 0.014 & 0.014 & $\begin{array}{l}\text { Author's } \\
\text { calculation } \\
\text { on Bank } \\
\text { of France } \\
\text { data. }\end{array}$ \\
\hline Size 1 & is 1 if [01 - 09] employees & $29.31 \%$ & & & & & \multirow{4}{*}{$\begin{array}{l}\text { Firm data } \\
\text { in DIANE }\end{array}$} \\
\hline Size2 & is 1 if [10 - 49] employees & $42.24 \%$ & & & & & \\
\hline Size3 & is 1 if [50 - 250] employees & $24.56 \%$ & & & & & \\
\hline Size4 & is 1 if [ $251-500]$ employees & $3.89 \%$ & & & & & \\
\hline Tech 1 & $\begin{array}{l}\text { is } 1 \text { if the firm is affiliated to } \\
\text { a low technology manufactur- } \\
\text { ing sector (NAF rév2 code = } \\
10-11-12-13-14-15-16 \\
-17-18-24-31)\end{array}$ & $34.71 \%$ & & & & & \multirow{4}{*}{$\begin{array}{l}\text { Firm data } \\
\text { in DIANE } \\
\text { and SESS } \\
\text { Classifica- } \\
\text { tion }\end{array}$} \\
\hline Tech 2 & $\begin{array}{l}\text { is } 1 \text { if the firm is affiliated to } \\
\text { a medium-low technology } \\
\text { manufacturing sector (NAF } \\
\text { rév2 code }=22-23-25-28 \\
-30.1-30.2-30.9-32-33 \text { ) }\end{array}$ & $50.99 \%$ & & & & & \\
\hline Tech 3 & $\begin{array}{l}\text { is } 1 \text { if the firm is affiliated to } \\
\text { a medium-high technology } \\
\text { manufacturing sector (NAF } \\
\text { rév2 code }=20-26.5-26.6 \\
-26.7-26.8-27.1-27.2- \\
27.3-27.4-27.9-29.1-29.2 \\
-29.3 \text { ) }\end{array}$ & $10.73 \%$ & & & & & \\
\hline Tech4 & $\begin{array}{l}\text { is } 1 \text { if the firm is affiliated to a } \\
\text { high technology manufactur- } \\
\text { ing sector (NAF rév2 code }= \\
21-26.1-26.2-26.3-26.4 \\
-30.3-30.4 \text { ) }\end{array}$ & $3.07 \%$ & & & & & \\
\hline
\end{tabular}




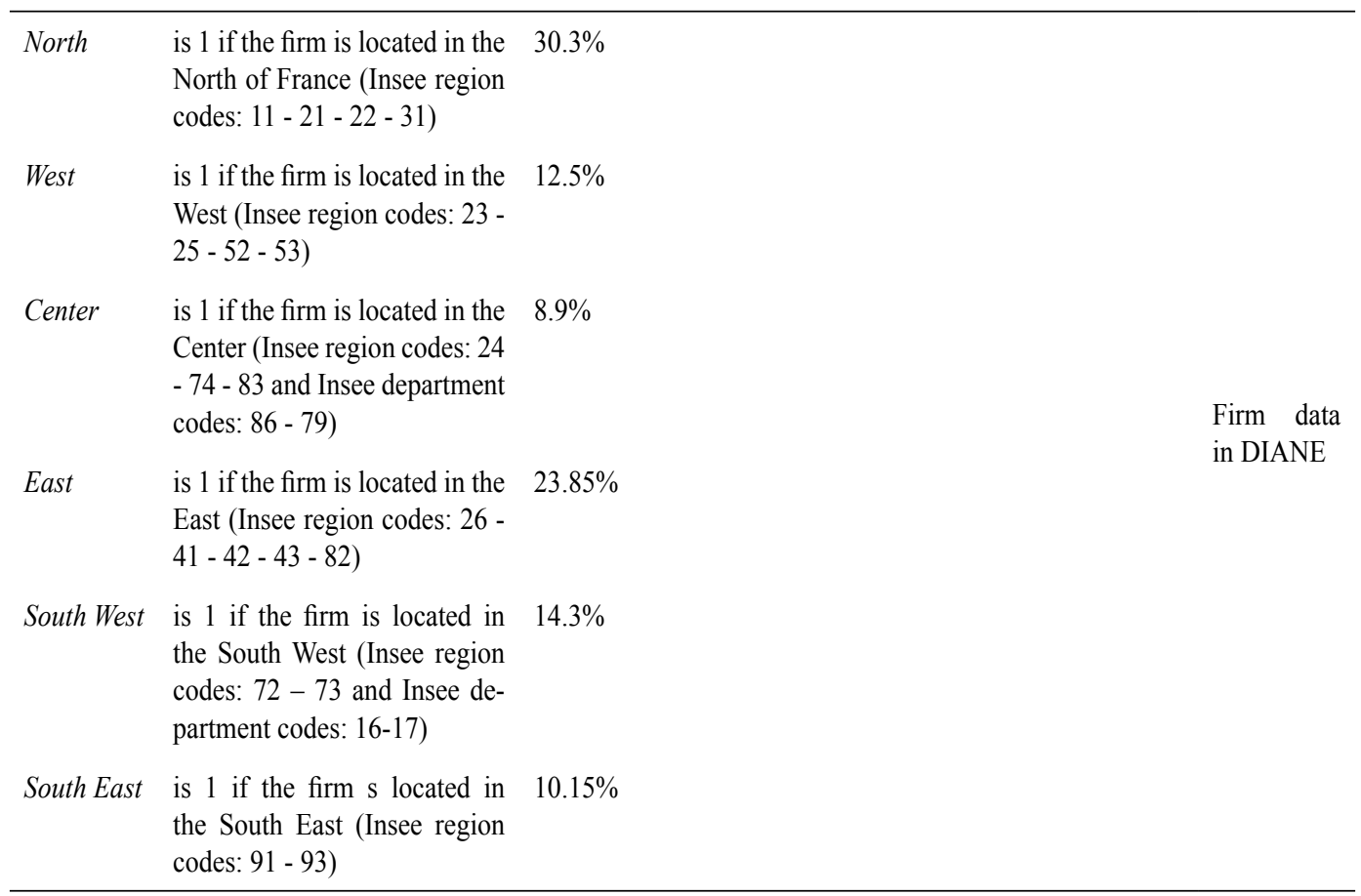

Note: $I$ : Investment is measured as the variation between $\mathrm{t}$ and $\mathrm{t}-1$ of the firm's capital stock (defined as tangible assets, gross of depreciation allowances). Investment $I_{i t}=K_{i t}-K_{i t-1}+\delta K_{i t-1}$ is deflated by the sectorial deflator of nominal investment (at 2000 prices). $K_{i t}$ is the net capital stock at the end of period t. $y$ : Logarithm of sales at 2000 prices. 


\section{Appendix C: French SMEs Investments' financing plan, 2004 - 2009}

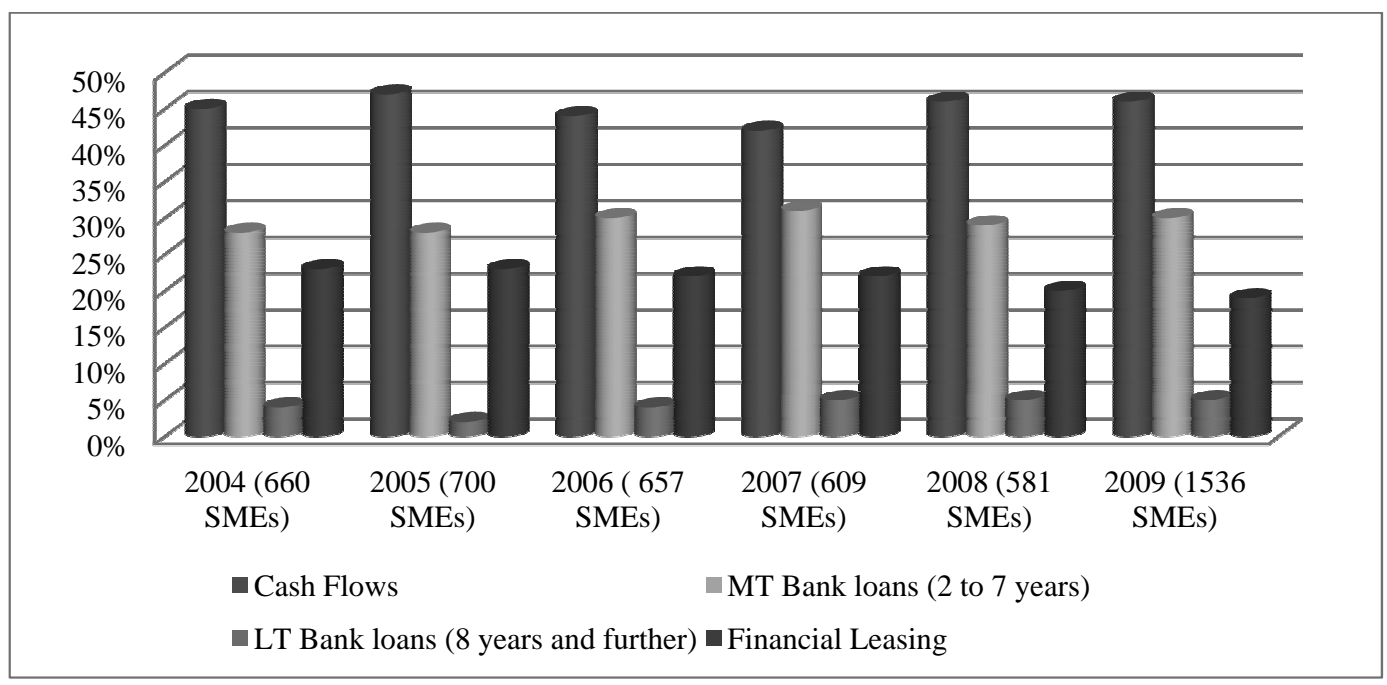

Source: the OSEO biannual surveys on SMEs and own elaboration.

\section{Appendix D: Specification tests}

\section{- The Arellano and Bond test of autocorrelation disturbance}

For consistent estimation, the system-GMM estimators require that the error $\varepsilon_{i, t}$ be serially uncorrelated.

Specifically, if $\varepsilon_{i, t}$ are serially uncorrelated, then $\Delta \varepsilon_{i, t}$ are correlated with $\Delta \varepsilon_{i, t-1}$, because $\operatorname{Cov}\left(\Delta \varepsilon_{i, t}, \Delta \varepsilon_{i, t-1}\right)=\operatorname{Cov}\left(\varepsilon_{i, t}-\varepsilon_{i, t-1}, \varepsilon_{i, t-1}-\varepsilon_{i, t-2}\right)=-\operatorname{Cov}\left(\varepsilon_{i, t-1}, \varepsilon_{i, t-1}\right) \neq 0$. But $\Delta \varepsilon_{i, t}$ will not be correlated with $\Delta \varepsilon_{i, t-k}$ for $k \geq 2$. A test of whether $\Delta \varepsilon_{i, t}$ are correlated with $\Delta \varepsilon_{i, t-k}$ for $k \geq 2$ can be calculated based on the correlation of the residuals $\Delta \hat{\varepsilon}_{i, t}$. The null hypothesis that $\operatorname{Cov}\left(\Delta \varepsilon_{i, t}, \Delta \varepsilon_{i, t-k}\right)=0$ for $k=1,2,3$ is rejected at a level of 0,05 if $p<0,05$. As explained, if $\varepsilon_{i, t}$ are serially uncorrelated, we expect to reject at order 1 but not at higher orders. This is indeed the case.

\section{- The overidentifying restrictions (OIR) test}

The validity of an instrument must be tested. This test cannot be performed in a justidentified model (a model in which the parameters' number is equal to instruments' number). But it is possible to test the validity of overidentifying instruments in an overidentified model provided that the parameters of the model are estimated using optimal GMM.

The starting point is the fitted value of the criterion function after optimal GMM, i.e., $Q(\hat{\beta})=\left\{\left(\frac{1}{N}\right)(y-X \hat{\beta})^{\prime} Z\right\} \hat{S}^{-1}\left\{\left(\frac{1}{N}\right) Z^{\prime}(y-X \hat{\beta})\right\}$ with $Z$ is the instruments matrix 
and $\hat{S}^{-1}=W$ with $W=\left(Z^{\prime} Z\right)^{-1}$ is a positive definite symmetric-weighting matrix. If the population moment conditions $E\left\{Z^{\prime}(y-X \hat{\beta})\right\}=0$ are correct, then $Z^{\prime}(y-X \hat{\beta}) \approx 0$, so $Q(\hat{\beta})$ should be clause to zero (for more details, see Roodman, 2009 and Verbeek, 2012). Under the null hypothesis that all instruments are valid, it can be shown that $Q(\hat{\beta})$ has an asymptotic chi-squared distribution with degrees of freedom equal to the number of overidentifying restrictions. Large values of $Q(\hat{\beta})$ lead to rejection of $H_{0}: E\left\{Z^{\prime}(y-X \hat{\beta}\}=0\right.$. Rejection is interpreted as indicating that at least one of the instruments is not valid. Here, for all specifications, all instruments are valid because $p>0,05$. 